\title{
Proteolytically stable foldamer mimics of host-defense peptides with protective activities in a murine model of bacterial infection
}

\author{
Emilie Teyssières, Jean-Philippe Corre, Stephanie Antunes, Catherine Rougeot, Christophe \\ Dugave, Grégory Jouvion, Paul Claudon, Guillain Mikaty, Céline Douat, Pierre L. Goossens \\ and Gilles Guichard
}

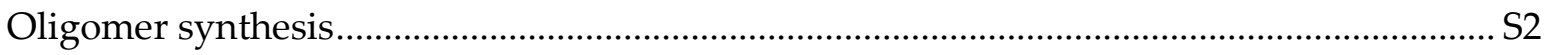

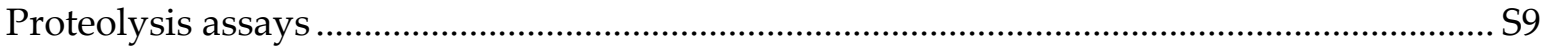

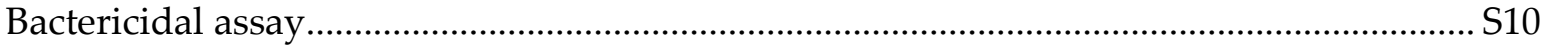

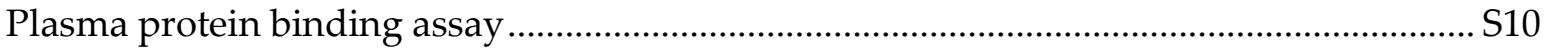

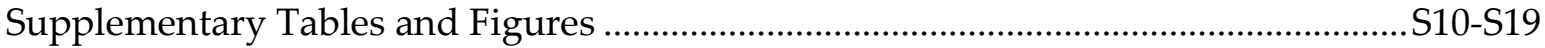

-Supplementary Table S1 : Results of protein binding (plasma, mouse, CD-1) performed with oligourea 1 -Supplementary Figure S1: Mapping of $\left[^{3} \mathbf{H}\right]-\mathbf{1}$ distribution in mouse renal (a) and naso-pharyngeal (b) tissues

-Supplementary Figure S2: Representative HPLC profiles of 1-related molecular populations present in extracts of mouse renal tissue 4 and $30 \mathrm{~h}$ after intravenous bolus administration of $\left.5 \mu \mathrm{Ci} / 100 \mu \mathrm{g} \mathrm{[}{ }^{3} \mathbf{H}\right]-\mathbf{1}$.

-Supplementary Figure S3: Bactericidal efficiency of dimer 7 against the germinated spores of B. anthracis.

-Supplementary Figure S4: Zoom of the NH/N'H region of the ${ }^{1} \mathrm{H}$ NMR spectra of $\mathbf{1}$ and $\mathbf{4 - 7}$ in $\mathrm{CD}_{3} \mathrm{OH}(400$ $\mathrm{MHz})$ at $25^{\circ} \mathrm{C}$.

-Supplementary Figure S5: ${ }^{1} \mathrm{H}$ NMR spectra of 1 and 4-7 in $\mathrm{CD}_{3} \mathrm{OH}(400 \mathrm{MHz})$ at $25^{\circ} \mathrm{C}$.

-Supplementary Table S2: ${ }^{1} \mathrm{H}$ NMR chemical shifts (in ppm) of $\mathbf{4}$ in $\mathrm{CD}_{3} \mathrm{OH}(400 \mathrm{MHz})$ at $25^{\circ} \mathrm{C}$.

-Supplementary Figure S6: Part of the ${ }^{1} \mathrm{H}$ NMR TOCSY spectrum of 4 in $\mathrm{CD}_{3} \mathrm{OH}(400 \mathrm{MHz})$ at $25^{\circ} \mathrm{C}$.

-Supplementary Table S3: ${ }^{1} \mathrm{H}$ NMR chemical shifts (in ppm) of $\mathbf{5}$ in $\mathrm{CD}_{3} \mathrm{OH}(400 \mathrm{MHz})$ at $25^{\circ} \mathrm{C}$.

-Supplementary Figure S7: Part of the ${ }^{1} \mathrm{H}$ NMR TOCSY spectrum of 5 in $\mathrm{CD}_{3} \mathrm{OH}(400 \mathrm{MHz})$ at $25^{\circ} \mathrm{C}$.

-Supplementary Table S4: ${ }^{1} \mathrm{H}$ NMR chemical shifts (in ppm) of 6 in $\mathrm{CD}_{3} \mathrm{OH}(400 \mathrm{MHz})$ at $25^{\circ} \mathrm{C}$

-Supplementary Figure S8: Part of the ${ }^{1} \mathrm{H}$ NMR TOCSY spectrum of 6 in $\mathrm{CD}_{3} \mathrm{OH}(400 \mathrm{MHz})$ at $25^{\circ} \mathrm{C}$.

-Supplementary Table S5: ${ }^{1} \mathrm{H}$ NMR chemical shifts (in ppm) of 7 in $\mathrm{CD}_{3} \mathrm{OH}(400 \mathrm{MHz})$ at $25^{\circ} \mathrm{C}$.

-Supplementary Figure S9: Part of the ${ }^{1} \mathrm{H}$ NMR TOCSY spectrum of 7 in $\mathrm{CD}_{3} \mathrm{OH}(400 \mathrm{MHz})$ at $25^{\circ} \mathrm{C}$.

-Supplementary Figure S10: Superimposition of the NH/N'H fingerprint region of the ${ }^{1} \mathrm{H}$ NMR TOCSY and the ROESY spectra (mixing time of $300 \mathrm{~ms}$ ) of 7 in $\mathrm{CD}_{3} \mathrm{OH}(400 \mathrm{MHz})$ at $25^{\circ} \mathrm{C}$. 


\section{Oligomer synthesis}

Commercially available reagents were used throughout without purification. MBHA resin (loading $1 \mathrm{mmol} / \mathrm{g}$ ), Boc- $\gamma-\mathrm{Val}-\mathrm{OH}$ and benzotriazole-1-yl-oxy-tris-(dimethylamino)-phosphonium hexa-fluorophosphate (BOP) reagent were purchased from PolyPeptide Laboratories France. $N, N$ '-diisopropylethylamine (DIEA) was purchased from Sigma-Aldrich. Solid phase peptide synthesis grade organic solvents (DMF, DCM) were used for solid phase synthesis and were purchased from Carlo Erba. RP-HPLC-quality acetonitrile $\left(\mathrm{CH}_{3} \mathrm{CN}\right)$ and MilliQ water were used for RP-HPLC analyses and purification. Most of the activated monomers used for solid phase synthesis were prepared using a previously reported procedure. ${ }^{1}$ Oligourea synthesis was performed manually under microwave irradiation (vide infra) on the Discover ${ }^{\circledR}$ System from CEM (CEM MWaves S.A.S., Orsay, France). Thin layer chromatography (TLC) was performed on silica gel 60 F254 (Merck) with detection by UV light and charring with $1 \%$ ninhydrin in ethanol followed by heating. Flash column chromatography was carried out on silica gel (40-63 $\mu \mathrm{m}$, Merck). RP-HPLC analyses were performed on a Dionex U3000SD using a Macherey-Nagel Nucleodur column $(4.6 \times 100 \mathrm{~mm}, 3 \mu \mathrm{m})$ at a flow rate of $1 \mathrm{~mL} \cdot \mathrm{min}^{-1}$. The mobile phase was

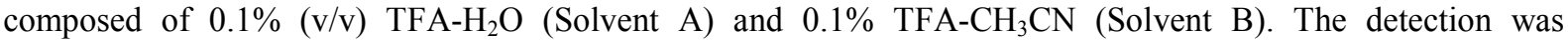
performed at $200 \mathrm{~nm}$ and the column temperature in the oven was $25^{\circ} \mathrm{C}$. Semi-preparative purifications of oligoureas were performed on a Gilson GX-281 system using a Macherey-Nagel Nucleodure column $(20 \times 250$ $\mathrm{mm}, 5 \mu \mathrm{m})$ at a flow rate of $20 \mathrm{~mL} \cdot \mathrm{min}^{-1}$. The mobile phase was similar as for the analytic system, unless otherwise notified. A gradient elution (0-20 min: $80 \%$ to $40 \%$ A) was applied at a flow rate of $20 \mathrm{~mL}^{\mathrm{min}}{ }^{-1}$. Column effluent was monitored by UV detection at 200, 214 and $254 \mathrm{~nm}$. The purity of the analyzed compounds was determined to be $95 \%$ by using the data processing a pplication of Chromoleon7 software. ESI-HRMS analyses were carried out on a ThermoElectron LCQ Advantage spectrometer equipped with an ion trap mass analyzer and coupled with a ThermoElectron Surveyor HPLC system.

The synthesis of $\mathbf{2}$ and $\mathbf{3}$ has been previously described. ${ }^{2}$

\section{Oligoureas Synthesis and Purification}

The oligomers were synthesized manually using Boc chemistry starting from MBHA resin ( $1 \mathrm{mmol} / \mathrm{g})$ and under microwave irradiation according to the procedure described in Douat et al. ${ }^{3}$ The first coupling step was performed with a solution of Boc- $\gamma^{4}-\mathrm{Val}-\mathrm{OH}$ (1.5 eq., relative to the resin loading) in DMF, with BOP (1.5 eq.) and DIEA (3 eq.) and the resin was shaken for 30 minutes. This coupling step was repeated once and after filtration the resin was successively washed with DMF $(5 \times 1 \mathrm{~mL})$ and $\mathrm{CH}_{2} \mathrm{Cl}_{2}(2 \times 1 \mathrm{~mL})$. Completion of the coupling was monitored by a Kaiser test. ${ }^{4}$ For each following coupling step, a solution of succinimidyl carbamate ( 3 eq. relative to the resin loading) and DIEA (6 eq.) in DMF was added on the resin, shaking was maintained for $15 \mathrm{~min}$ at $70{ }^{\circ} \mathrm{C}$ with microwave irradiation at $25 \mathrm{~W}$. A double coupling was performed systematically. The coupling solution was then filtered off and the resin was washed with DMF $(5 \times 1 \mathrm{~mL})$ and $\mathrm{CH}_{2} \mathrm{Cl}_{2}(2 \times 1 \mathrm{~mL})$. Completion of couplings was monitored with the Chloranil test. ${ }^{5}$ Boc protecting group was removed using TFA at room temperature $(2 \times 5 \mathrm{~min})$. TFA was removed by filtration and the resin was washed with $\mathrm{CH}_{2} \mathrm{Cl}_{2}(3 \times 1 \mathrm{~mL})$ and with DMF $(3 \times 1 \mathrm{~mL})$. End capping was performed with the appropriate reagent as indicated below. Finally, the resin was washed with $\mathrm{CH}_{2} \mathrm{Cl}_{2}$ and dried under vacuum. Cleavage of the oligomer from the resin and deprotection of the side-chain temporary protection were performed simultaneously by treatment with HF (containing $10 \% \mathrm{p}$-cresol as a scavenger) for $60 \mathrm{~min}$ at $0^{\circ} \mathrm{C}$. The expected oligomer was finally precipitated from the resin with diethylether and lyophilized before purification by semi-preparative RPHPLC $(20-100 \%$ of B in $20 \mathrm{~min}$ or $35-75 \%$ B in $20 \mathrm{~min})$. The yields are calculated after RP-HPLC semipreparative purification based on the resin loading.

1. Violette, A.; Fournel, S.; Lamour, K.; Chaloin, O.; Frisch, B.; Briand, J. P.; Monteil, H.; Guichard, G. Mimicking helical antibacterial peptides with nonpeptidic folding oligomers. Chem. Biol. 2006, 13, 531-538.

2. Claudon, P.; Violette, A.; Lamour, K.; Decossas, M.; Fournel, S.; Heurtault, B.; Godet, J.; Mely, Y.; Jamart-Gregoire, B.; Averlant-Petit, M. C.; Briand, J. P.; Duportail, G.; Monteil, H.; Guichard, G. Consequences of isostructural main-chain modifications for the design of antimicrobial foldamers: helical mimics of host-defense peptides based on a heterogeneous amide/urea backbone. Angew. Chem. Int. Ed. Engl. 2010, 49, 333-336.

3. Douat, C.; Aisenbrey, C.; Antunes, S.; Decossas, M.; Lambert, O.; Bechinger, B.; Kichler, A.; Guichard, G. A CellPenetrating Foldamer with a Bioreducible Linkage for Intracellular Delivery of DNA. Angew. Chem. Int. Ed. 2015, 54, $11133-11137$.

4. Kaiser, E.; Colescott, R. L.; Bossinger, C. D.; Cook, P. I. Color test for detection of free terminal amino groups in the solid-phase synthesis of peptides, Anal. Biochem., 1970, 34, 595-598.

5. Vojkovsky, T. Detection of secondary-amines on solid-phase, Peptide Res., 1995, 8, 236-237. 


\section{Oligourea 1}

The synthesis was performed on a $100 \mu \mathrm{mol}$ scale. End capping of the terminal amine with isopropylisocyanate (3 eq.) was performed twice in $1 \mathrm{~mL}$ of DMF, in the presence of DIEA (6 eq.) at room temperature for $15 \mathrm{~min}$. Cleavage from the resin by treatment with $\mathrm{HF}$ gave $88 \mathrm{mg}$ of crude oligourea with a purity of $69 \%$. Yield after HPLC purification: $43.9 \mathrm{mg}, 31 \%$; HRMS $\left(\mathrm{ES}^{+}\right): \mathrm{m} / z$ calcd for $\mathrm{C}_{68} \mathrm{H}_{119} \mathrm{~N}_{22} \mathrm{O}_{9}{ }^{+}[\mathrm{M}+\mathrm{H}]^{+} 1387.95249$ found 1387.96563; RP-HPLC $t_{\mathrm{R}} 6.75 \mathrm{~min}$; (linear gradient, 10-100\% B, $10 \mathrm{~min}$ ).
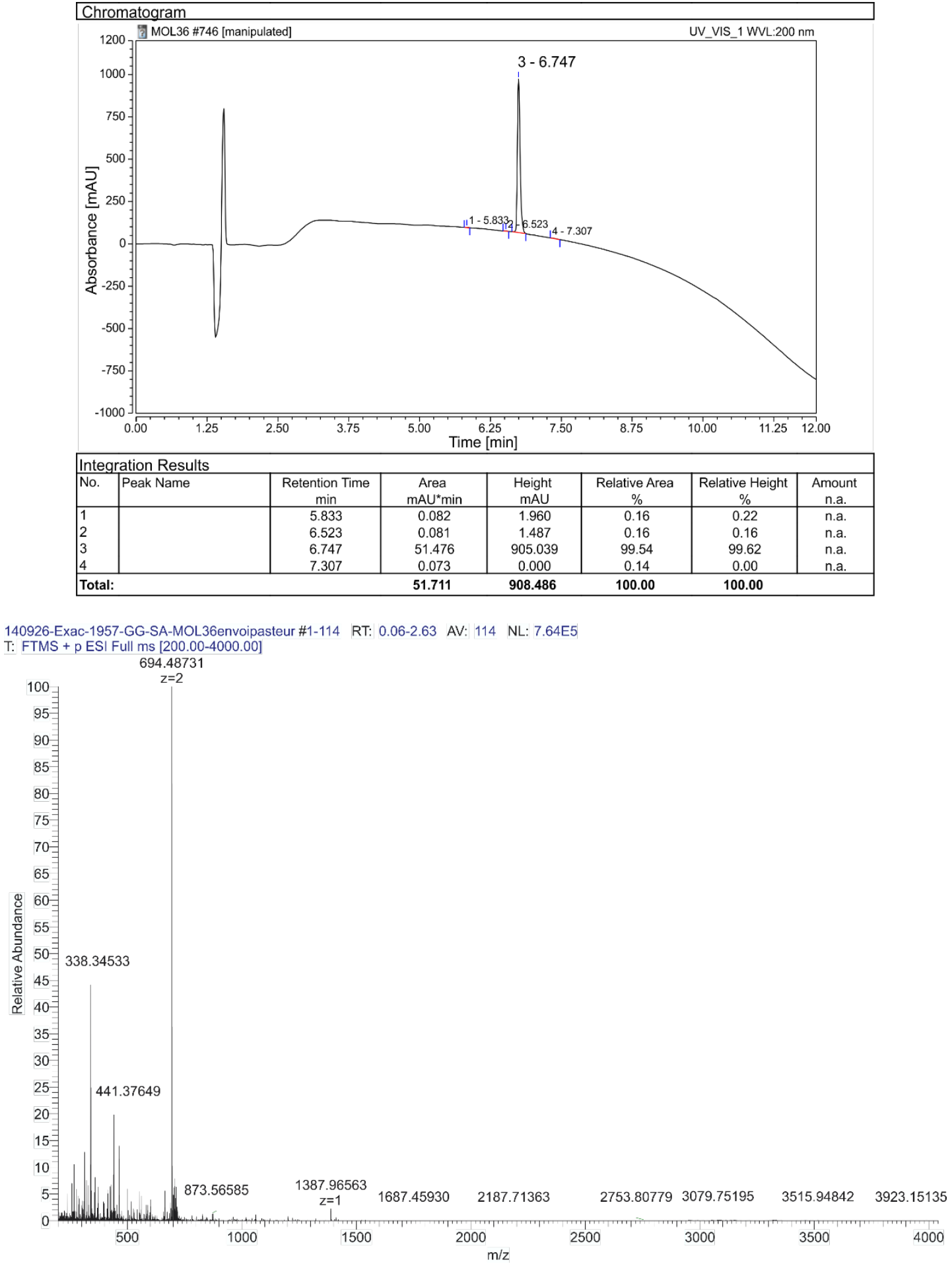

\section{Oligourea 4}

The synthesis was performed on a $200 \mu \mathrm{mol}$ scale. End capping of the terminal amine with 1.5 eq of Biotine, coupled twice at room temperature for $30 \mathrm{~min}$, with 3 eq. DIEA, 3 eq. BOP and 3 eq. HOBt in DMF (2 ml). Cleavage from the resin by treatment with HF gave $116 \mathrm{mg}$ of crude oligourea with a purity of $72 \%$. Yield after 
purification: $43 \mathrm{mg}, 12 \%$; HRMS $\left(\mathrm{ES}^{+}\right): \mathrm{m} / z$ calcd for $\mathrm{C}_{74} \mathrm{H}_{126} \mathrm{~N}_{23} \mathrm{O}_{10} \mathrm{~S}^{+}[\mathrm{M}+\mathrm{H}]^{+} 1528.97787$ found 1529.97578; RPHPLC $t_{\mathrm{R}} 5.267 \mathrm{~min}$ (linear gradient, 20-100\% B, $10 \mathrm{~min}$ ).

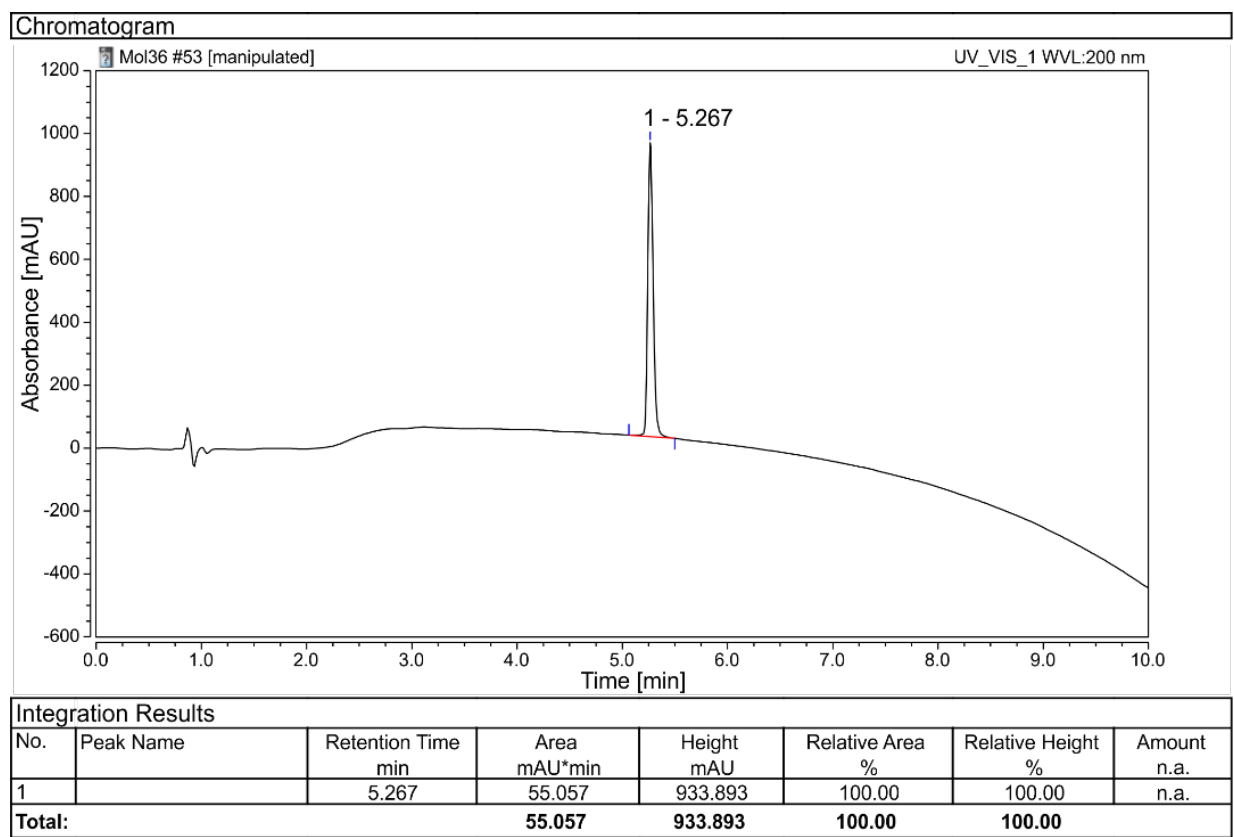

150320-Exac-2249-GG-SA-SA056Mol36Biotine \#1-80 RT: 0.03-1.19 AV: 80 NL: $1.88 E 7$ T: FTMS + p ESI Full ms [100.00-2000.00]

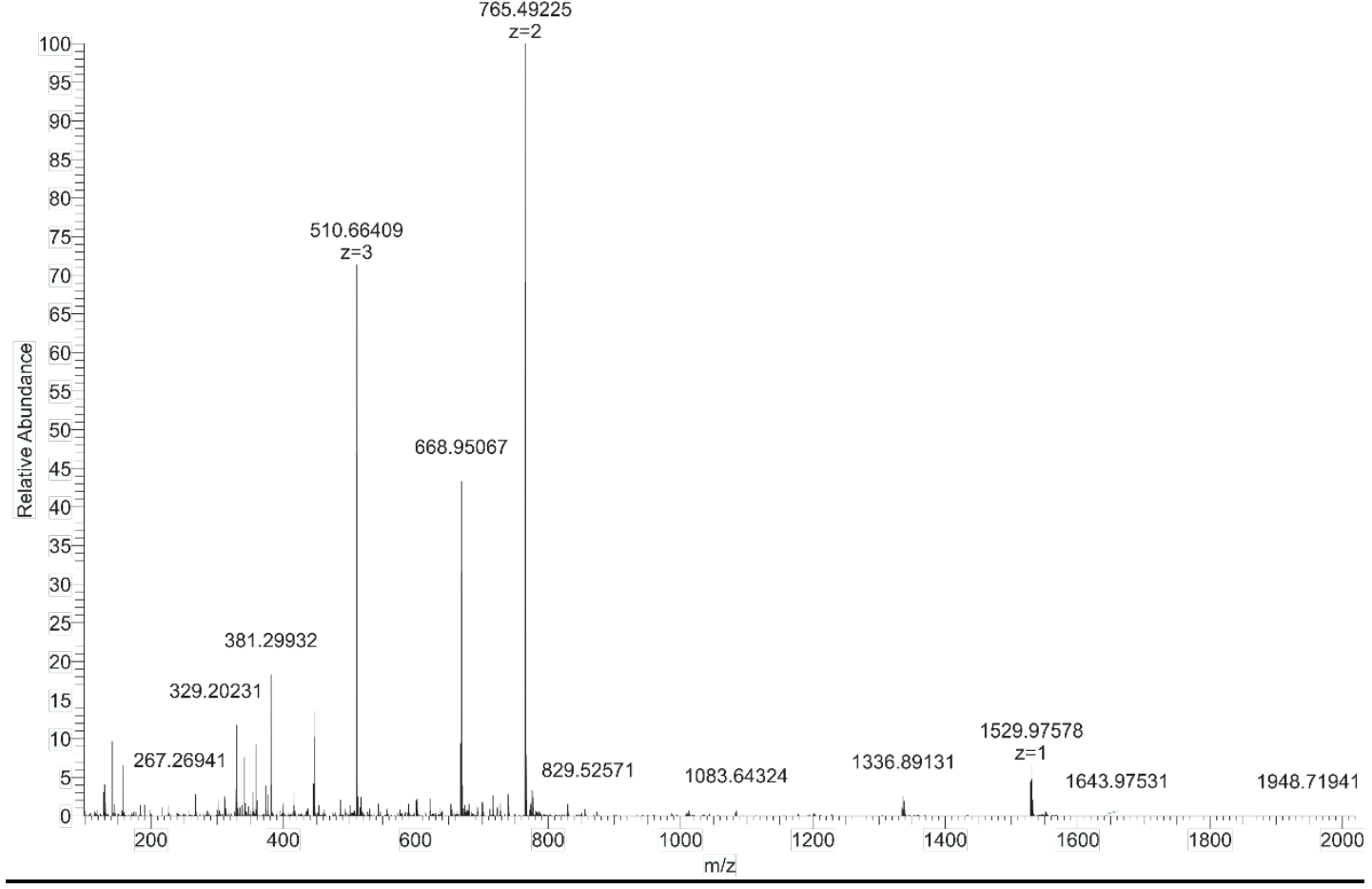

\section{Oligourea 5}

The synthesis was performed on a $133 \mu \mathrm{mol}$ scale. The cysteamine termination was added by a double coupling 1.5 eq. of TrtS-SH$\left(\mathrm{CH}_{2}\right)_{2} \mathrm{NHOSu}$ with 3 eq. of DIEA on microwave conditions $\left(70{ }^{\circ} \mathrm{C}, 25 \mathrm{~W}, 15\right.$ min then 30 $\mathrm{min})$. Cleavage from the resin by treatment with $\mathrm{HF}$ gave $191 \mathrm{mg}$ of crude oligourea with a purity of $51 \%$. Yield after HPLC purification: $58.8 \mathrm{mg}, 31 \%$; HRMS $\left(\mathrm{ES}^{+}\right): \mathrm{m} / z$ calcd for $\mathrm{C}_{67} \mathrm{H}_{117} \mathrm{~N}_{22} \mathrm{O}_{9} \mathrm{~S}^{+}[\mathrm{M}+\mathrm{H}]^{+} 1405.90891$ found 1405.91284; RP-HPLC $t_{\mathrm{R}} 6.27$ min (linear gradient, 10-100\% B, $10 \mathrm{~min}$ ). 


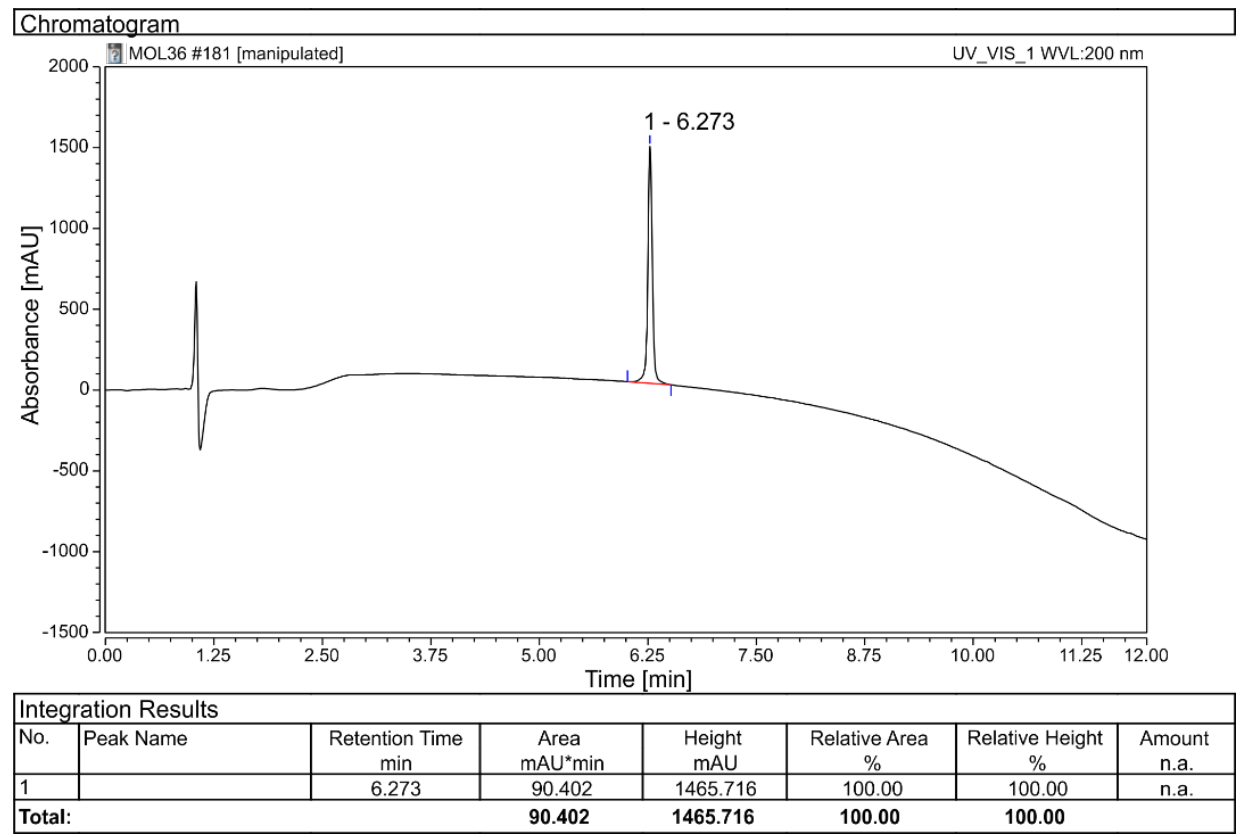

150403-Exac-2263-GG-SA-Mol36SHBOC \#1-409 RT: 0.03-5.96 AV: 409 NL: $5.70 E 7$ T: FTMS + p ESI Full ms [100.00-2000.00]

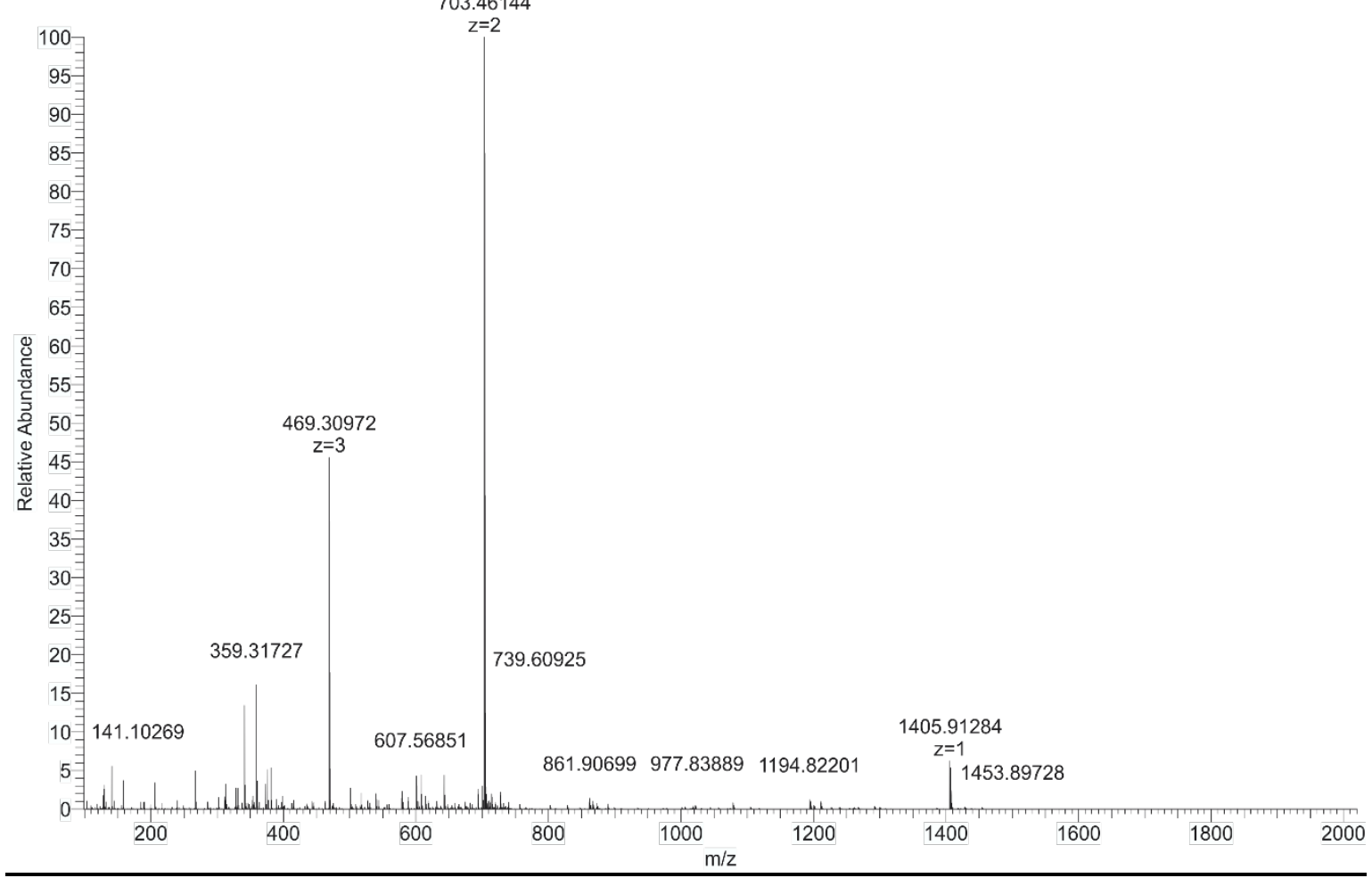




\section{Oligourea 6}

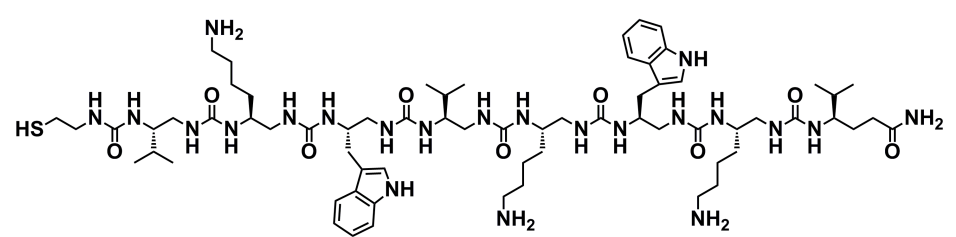

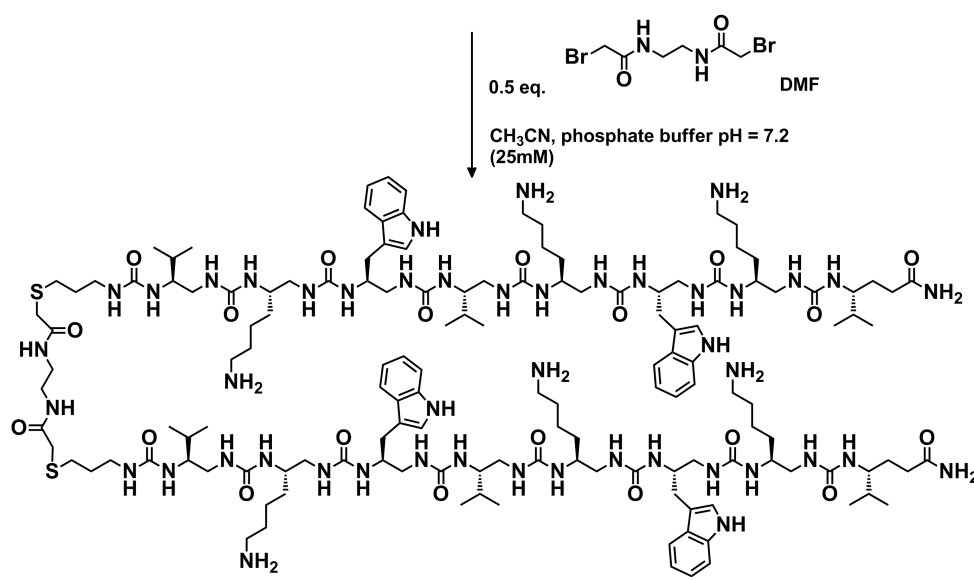

5 was dimerized to 6 according to the procedure published by Staples et al. ${ }^{6} \mathbf{5}(14 \mathrm{mg}, 0.01 \mathrm{mmol})$ was solubilized in a mixture of $1 \mathrm{~mL}$ of $0.1 \mathrm{M}$ phosphate buffer $(\mathrm{pH} 7.5)$ and $250 \mu \mathrm{L}$ of MeCN. A solution of the bisbromoacetamide linker ${ }^{7}$ was prepared in DMF $(5.3 \mathrm{mg}$ in $53 \mu \mathrm{L})$. One aliquot of the linker solution $(5 \mu \mathrm{L})$ was added immediately. The reaction was placed in a dry bath at $65^{\circ} \mathrm{C}$ and allowed to stir for 2 hours with four additional aliquots of linker being added in 15 minute intervals for the first hour ( $25 \mu \mathrm{L}$ linker total). The $\mathrm{pH}$ was checked overtime (around 7.5) and the reaction was followed by HPLC. After completion, the mixture was lyophilized and purified using semi-preparative $\operatorname{HPLC~}\left(35-45 \% \mathrm{~B}, 30 \mathrm{~min}, 50^{\circ} \mathrm{C}\right) .7 .7 \mathrm{mg}$ of pure compound was obtained (55\% yield); HRMS (ES $\left.{ }^{+}\right): m / z$ calcd for $\mathrm{C}_{140} \mathrm{H}_{241} \mathrm{~N}_{46} \mathrm{O}_{20} \mathrm{~S}_{2}{ }^{+}[\mathrm{M}+\mathrm{H}]^{+} 2951.87303$ found 2951.89858; RP-HPLC $t_{\mathrm{R}} 5.97 \mathrm{~min}$ (linear gradient, $10-100 \% \mathrm{~B}, 10 \mathrm{~min}$ ).

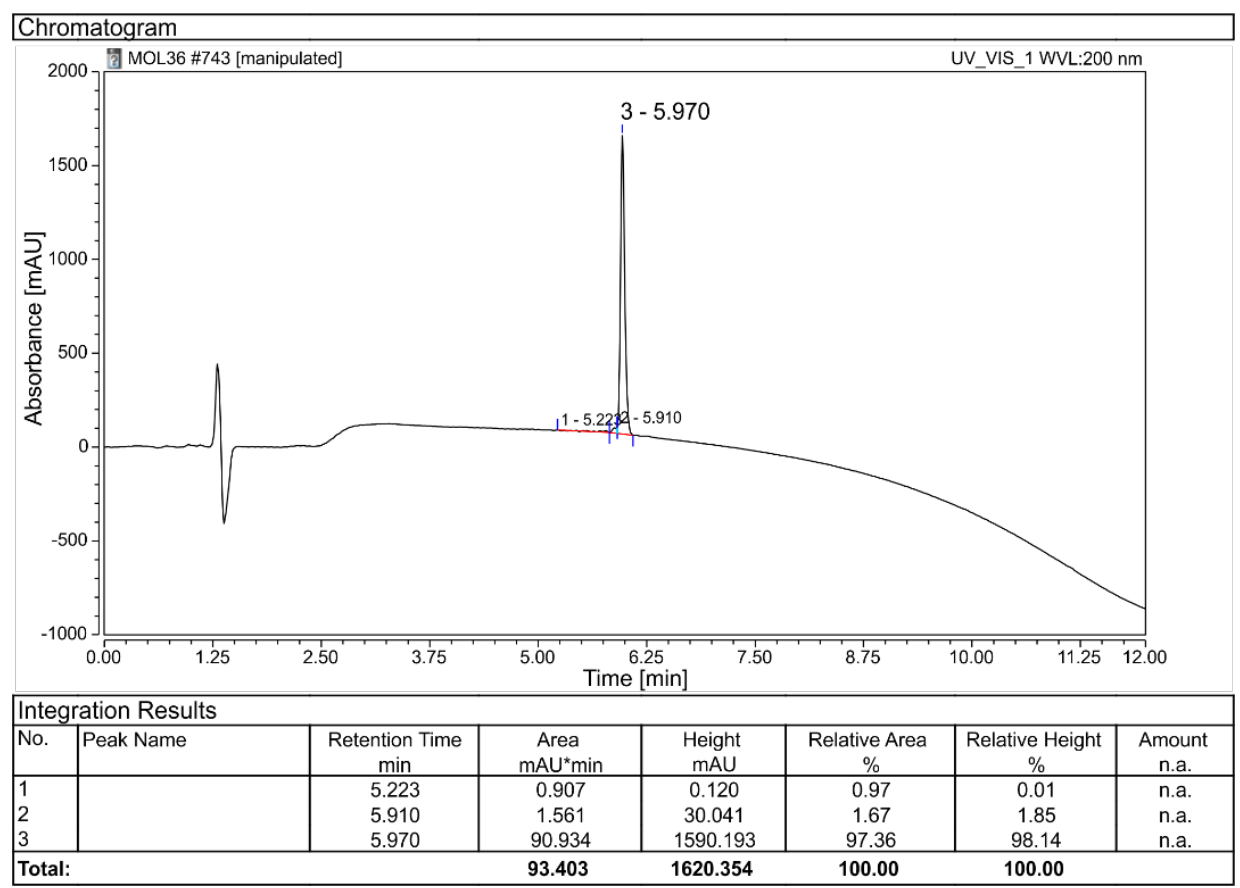

6. Staples, J. K.; Oshaben, K. M.; Horne, W. S. A modular synthetic platform for the construction of protein-based supramolecular polymers via coiled-coil self-assembly. Chem. Sci. 2012, 3, 3387-3392..

7. Kim, Y. H.; Stites, W. E. Effects of excluded volume upon protein stability in covalently cross-linked proteins with variable linker lengths, Biochemistry, 2008, 47, 8804-8814. 


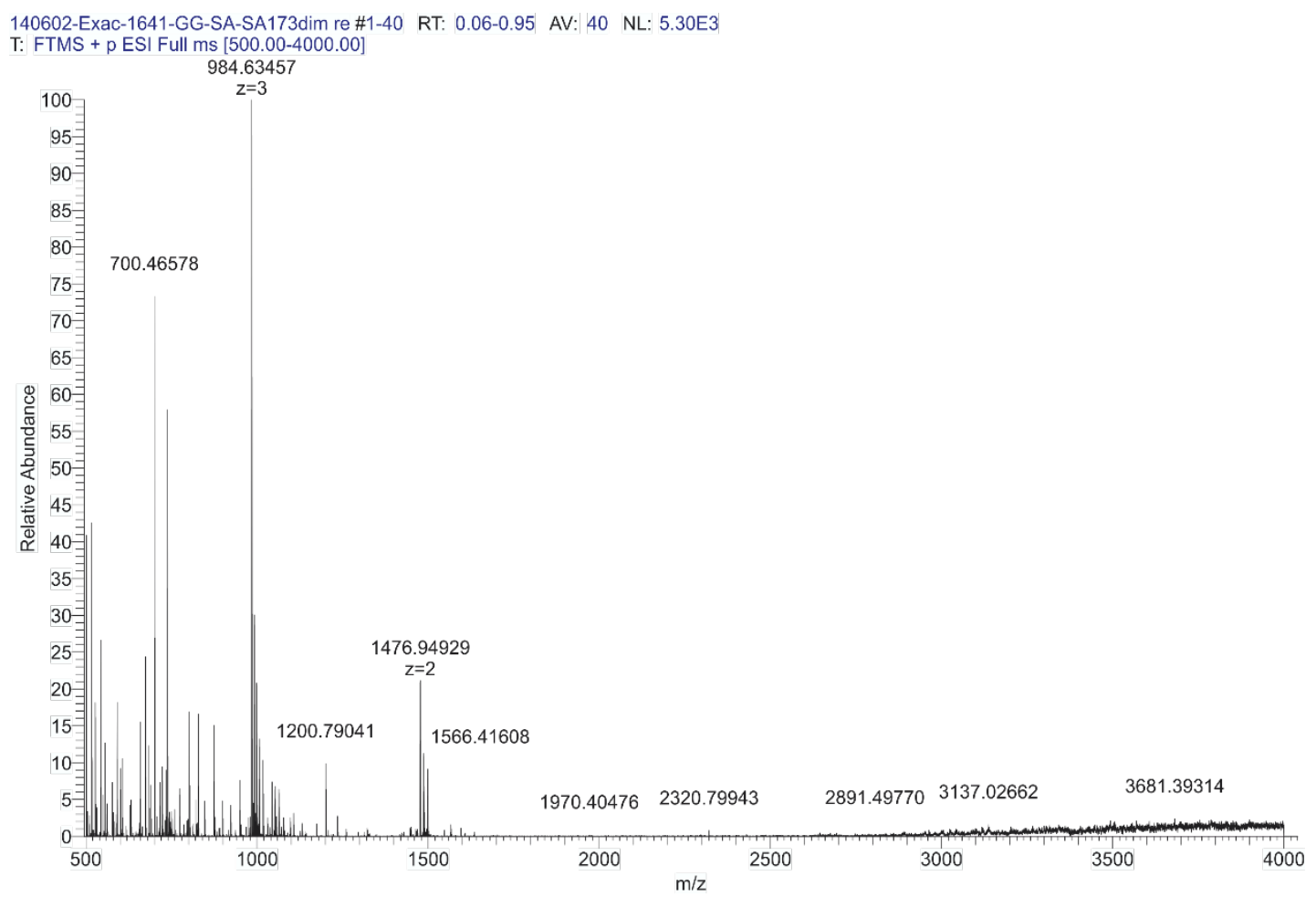

\section{Oligourea 7}

5 was dimerized to 7 according to the procedure published by Douat et al. ${ }^{3} 5(16 \mathrm{mg}, 0.011 \mathrm{mmol})$ was solubilized in $200 \mu \mathrm{L}$ of pure in milliQ water and $2 \times 80 \mu \mathrm{L}$ of $50 \mathrm{mM}$ solution of $\mathrm{NH}_{4} \mathrm{HCO}_{3}(20 \mathrm{mM})$ was added to reach a pH around $8.80 \mu \mathrm{L}$ of Bis(5-nitro-2-pyridyl) disulfide (NPyS) $2_{2}(45.4 \mathrm{mM}$ in acetonitrile) was next added and the reaction was left 4 hours to ensure a complete dimerization to occur. Completion of the reaction was checked by HPLC and the reaction mixture was lyophilized. The lyophilized crude was directly purified on semi-prep HPLC (30-65\% B, $20 \mathrm{~min}$ ). $5 \mathrm{mg}$ of pure compound was obtained (30\% yield); HRMS $\left(\mathrm{ES}^{+}\right): m / z$ calcd for $\mathrm{C}_{134} \mathrm{H}_{231} \mathrm{~N}_{44} \mathrm{O}_{18} \mathrm{~S}_{2}{ }^{+}[\mathrm{M}+\mathrm{H}]^{+} 2809.79880$ found 2809.80930; RP-HPLC $t_{\mathrm{R}} 6.41$ min (linear gradient $30-65 \% \mathrm{~B}, 10 \mathrm{~min})$.

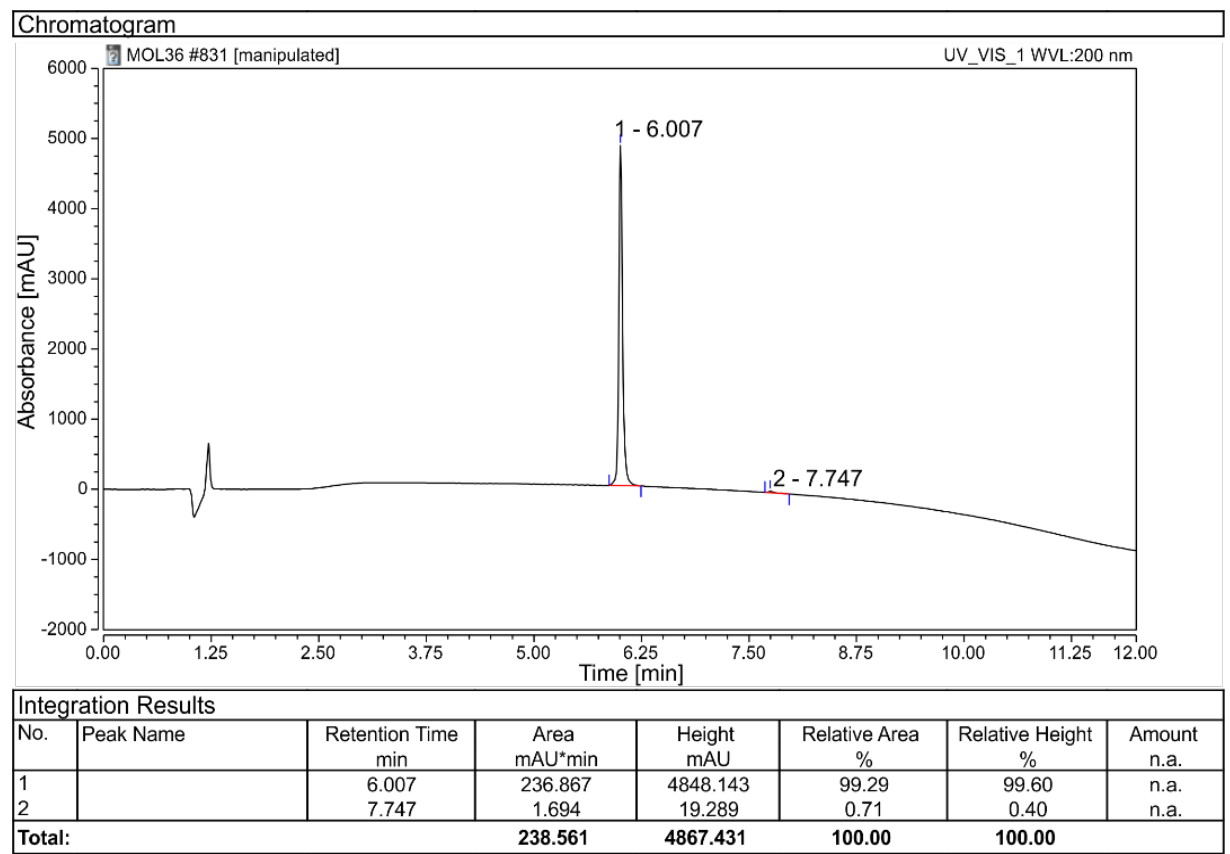




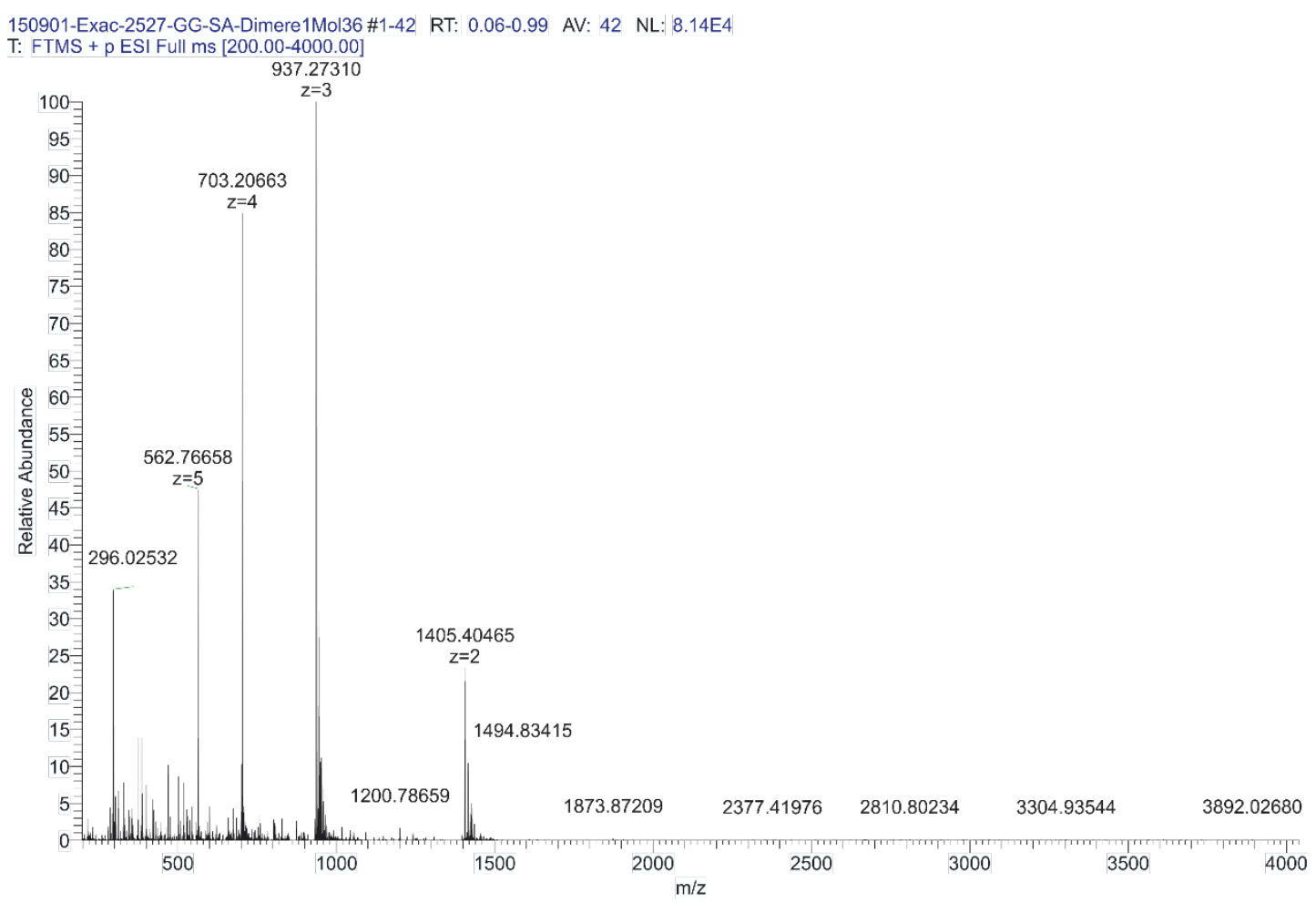

\section{$\underline{\text { Peptide } 8}$}

Synthesis of peptide 8 was performed on Fmoc-Rink amide-PS resin (substitution $0.52 \mathrm{mmol} / \mathrm{g}$ ) at $0.1 \mathrm{mmol}$ scale. The resin was loaded in LibertyBLUE microwave-assisted automatic synthesizer (CEM MWaves S.A.S., Orsay, France). Fmoc deprotection with $20 \%$ piperidine in DMF was accelerated with microwave heating at 75 ${ }^{\circ} \mathrm{C}$ for $30 \mathrm{~s}$ and was repeated once after filtration at $75{ }^{\circ} \mathrm{C}$ for $180 \mathrm{~s}$. In each following step, Fmoc-amino acids were added with coupling reagents DIC and ethyl 2-cyano-2-(hydroxyimino)acetate (oxyma) in a molar ratio of 5:5:5 of the resin loading. The microwave-assisted coupling reaction was set to heat for $300 \mathrm{~s}$ to increase temperature from ambient temperature to $75^{\circ} \mathrm{C}$. The synthesis of $\mathbf{8}$ was performed following a single coupling method.

A $3 \mathrm{~mL}$ cleavage cocktail consisting of 95\% trifluoroacetic acid (TFA), 2.5\% water, 2.5\% triisopropylsilane (TIS) was then added to the resin for cleavage of the peptide and removal of the protecting groups. The resin was cleaved at RT for $1.5 \mathrm{~h}$ with gentle shaking. The crude peptide was precipitated using $10 \mathrm{~mL}$ cold diethyl ether and rinsed with diethyl ether twice. The precipitant powder was immediately redissolved in $\mathrm{CH}_{3} \mathrm{CN} / \mathrm{H}_{2} \mathrm{O} / 0.1 \%$ TFA before lyophilization. Peptide 8 was used for proteolysis assay without further purification. MS (ES ${ }^{+} \mathrm{m} / \mathrm{z}$ $1113.6824[\mathrm{M}+\mathrm{H}]^{+}, 557.3556[\mathrm{M}+2 \mathrm{H}]^{2+}, 371.9042[\mathrm{M}+3 \mathrm{H}]^{3+}$ RP-HPLC $t_{\mathrm{R}} 6.67$ min (linear gradient 10-100\% $\mathrm{B}, 10 \mathrm{~min})$. 


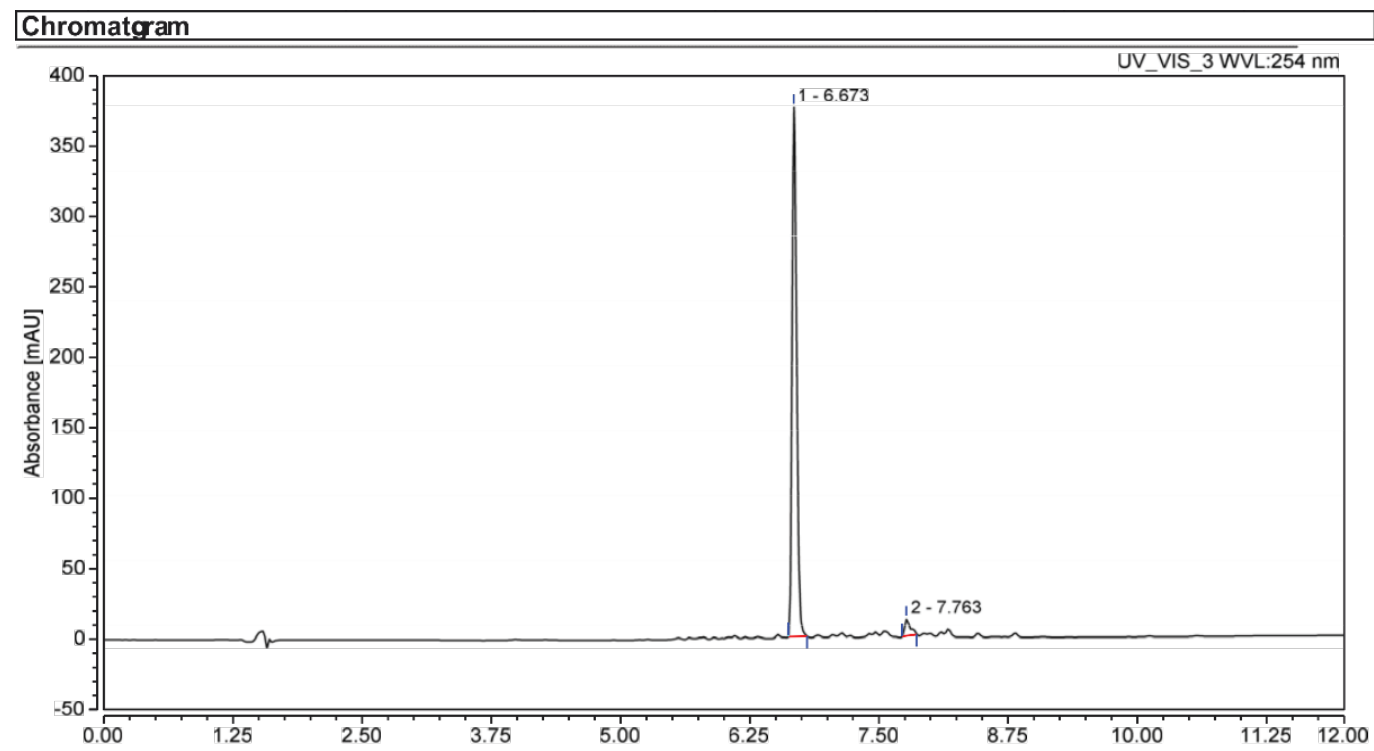

\begin{tabular}{|l|l|c|c|c|c|c|c|}
\hline Integration Results \\
\hline No. & Peak Name & $\begin{array}{c}\text { Retention Time } \\
\text { min }\end{array}$ & $\begin{array}{c}\text { Area } \\
\mathrm{mAU}^{*} \min \end{array}$ & $\begin{array}{c}\text { Height } \\
\mathrm{mAU}\end{array}$ & $\begin{array}{c}\text { Relative Area } \\
\%\end{array}$ & $\begin{array}{c}\text { Relative Height } \\
\%\end{array}$ & $\begin{array}{c}\text { Amount } \\
\text { n.a. }\end{array}$ \\
\hline 1 & & 6.673 & 19.477 & 376.005 & 96.10 & 96.84 & n.a. \\
2 & 7.763 & 0.791 & 12.255 & 3.90 & 3.16 & n.a. \\
\hline Total: & $\mathbf{2 0 . 2 6 8}$ & $\mathbf{3 8 8 . 2 6 0}$ & 100.00 & 100.00 \\
\hline
\end{tabular}

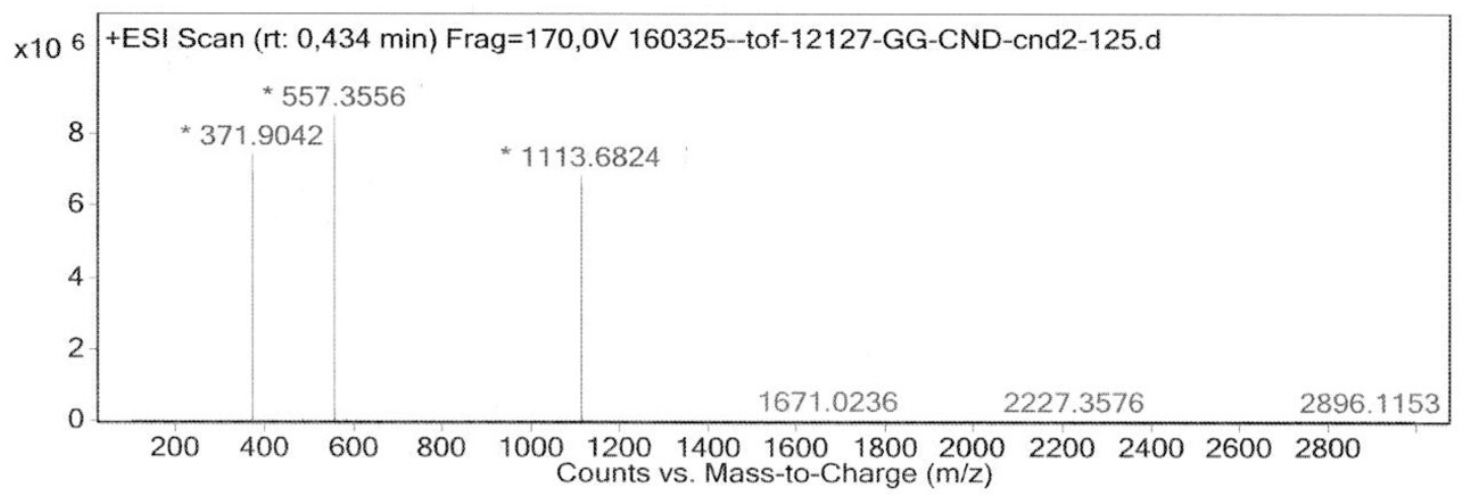

\section{Proteolysis assays}

Stabilities of oligourea $\mathbf{1}$ and corresponding peptide sequence $\mathbf{8}$ to pronase E, trypsin, and chymotrypsin were determined by performing protease reaction assays in 96-well polypropylene plates at room temperature. ${ }^{8}$ To each well was added an aqueous buffer $(40 \mu \mathrm{L} ; 10 \mathrm{mM}$ Tris, $\mathrm{pH} 7.5$ for pronase $\mathrm{E}$ and trypsin or $10 \mathrm{mM}$ Tris, pH 8.0 for chymotrypsin), an enzyme solution in the appropriate buffer $\left(1.7 \mu \mathrm{L} ; 1.0 \mathrm{mg} . \mathrm{mL}^{-1}\right.$ pronase $\mathrm{E}, 0.1$ mg. $\mathrm{mL}^{-1}$ chymotrypsin, or $0.1 \mathrm{mg} / \mathrm{mL}^{-1}$ trypsin), and a solution of the oligomer to be assayed ( $8.3 \mu \mathrm{L} ; 2.0 \mathrm{mM}$ in the enzyme-specific buffer). One control well for each oligomer assayed contained no protease. All experiments have been carried out in duplicates two times. At specific time points after addition of $\mathbf{1}$ or $\mathbf{8}$ to protease solutions the reactions were quenched with a solution of TFA in water $(5 \% \mathrm{v} / \mathrm{v}, 100 \mu \mathrm{L})$. Reaction progress over time was quantified by HPLC analysis of the quenched reaction solutions with use of a C18 analytical column (linear gradient $10-60 \%$ B, 5 min and see above for C18 column characteristics). If the degradation of peptide 8 was really fast in the presence of protease solutions, oligourea $\mathbf{1}$ was not degraded in the presence of proteases over $24 \mathrm{~h}$.

\footnotetext{
${ }^{8}$ Sadowsky, J. D.; Murray, J. K.; Tomita, Y.; Gellman, S. H. Exploration of Backbone Space in Foldamers Containing $\alpha$ - and $\beta$-Amino Acid Residues: Developing Protease-Resistant Oligomers that Bind Tightly to the BH3-Recognition Cleft of BclxL. ChemBioChem 2007, 8, 903-916.
} 


\section{Bactericidal assay}

The spores after germination induction were obtained after a 5-min incubation in brain-heart infusion medium (BHI, Difco) at $37^{\circ} \mathrm{C}$. The germination efficiency was immediately checked by phase contrast microscopy and retrospectively by CFU counts and was always $>85 \%$. To obtain encapsulated bacilli, spores of the $9602 \mathrm{P}$ strain obtained after germination induction in $\mathrm{BHI}$ were incubated in $\mathrm{R}$ medium ${ }^{9}$ with $\mathrm{NaHCO}_{3}(0.6 \%$ final $)$ in $5 \% \mathrm{CO}_{2}$ for a further 75 minutes at $37^{\circ} \mathrm{C}$ with continuous shaking. Encapsulation was checked by light microscopy, using India ink coloration. Non-encapsulated bacilli were obtained with the same experimental procedures with spores of non-encapsulated 9602PR strain.

The lyophilised molecules were solubilised extemporaneously in sterile distilled water at an appropriate concentration according to the experiments. The actual concentration was measured through absorbance at 280 $\mathrm{nm}$ with a Nanodrop spectrophotometer (ND1000 - Nyxor Biotechnologies), taking into account the two $\operatorname{Trp}^{\mathrm{u}} / \gamma \operatorname{Trp}$ residues present in these molecules and the molar extinction coefficient of the indole group $\left(\varepsilon_{280}=\right.$ $5700 / \mathrm{mmol} / \mathrm{ml})$. The concentration $(\mu \mathrm{g} / \mathrm{mL})$ was determined as: Absorbance $(280 \mathrm{~nm}) \times \mathrm{MM} / 5700 \times 2$.

\section{Plasma protein binding assay}

Plasma protein binding was performed by the equilibrium dialysis technique in a 96-well format assay. ${ }^{10}$ Mouse (CD-1) plasma was used as the default protein containing matrix. The protein matrix was spiked with the oligourea 1 at $10 \mu \mathrm{M}$ (by default, $\mathrm{n}=2$ ) with a final DMSO concentration of $1 \%$. The dialysate compartment was loaded with phosphate buffered saline (PBS, pH 7.4) and the sample side was loaded with equal volume of the spiked protein matrix. The dialysis plate was then sealed and incubated at $37{ }^{\circ} \mathrm{C}$ for $4 \mathrm{~h}$. After the incubation, samples were taken from each compartment, diluted with the phosphate buffer followed by addition of acetonitrile and centrifugation. The supernatants were then used for HPLC-MS/MS analysis. Acebutolol, and quinidine were tested in each assay as reference compounds with low and medium protein binding values, respectively. The percent bound to proteins is calculated as follows:

Protein binding $(\%)=\frac{\operatorname{Area}_{\mathrm{p}}-\text { Are }_{\mathrm{b}}}{\operatorname{Area}_{\mathrm{p}}}$

$A r e a_{\mathrm{p}}=$ Peak area of analyte in the protein matrix

$A r e a_{\mathrm{b}}=$ Peak area of analyte in the Assay Buffer

\section{Supplementary Tables and Figures}

\begin{tabular}{l|c|c|c} 
& $\mathbf{1}$ & Acebutolol & Quinidine \\
\hline Protein Bound (\%) & 99 & 3 & 78
\end{tabular}

Supplementary Table S1. Results of protein binding (plasma, mouse, CD-1) performed with oligourea 1 and two reference compounds: acebutolol and quinidine.

\footnotetext{
${ }^{9}$ Ristroph, J. D.; Ivins, B. E. Elaboration of Bacillus anthracis antigens in a new, defined culture medium. Infect. Immun. 1983, 39, 483-486.

${ }^{10}$ Banker, M. J.; Clark, T. H.; Williams, J. A. Development and validation of a 96-well equilibrium dialysis apparatus for measuring plasma protein binding. J. Pharm. Sci. 2003, 92, 967-974.
} 


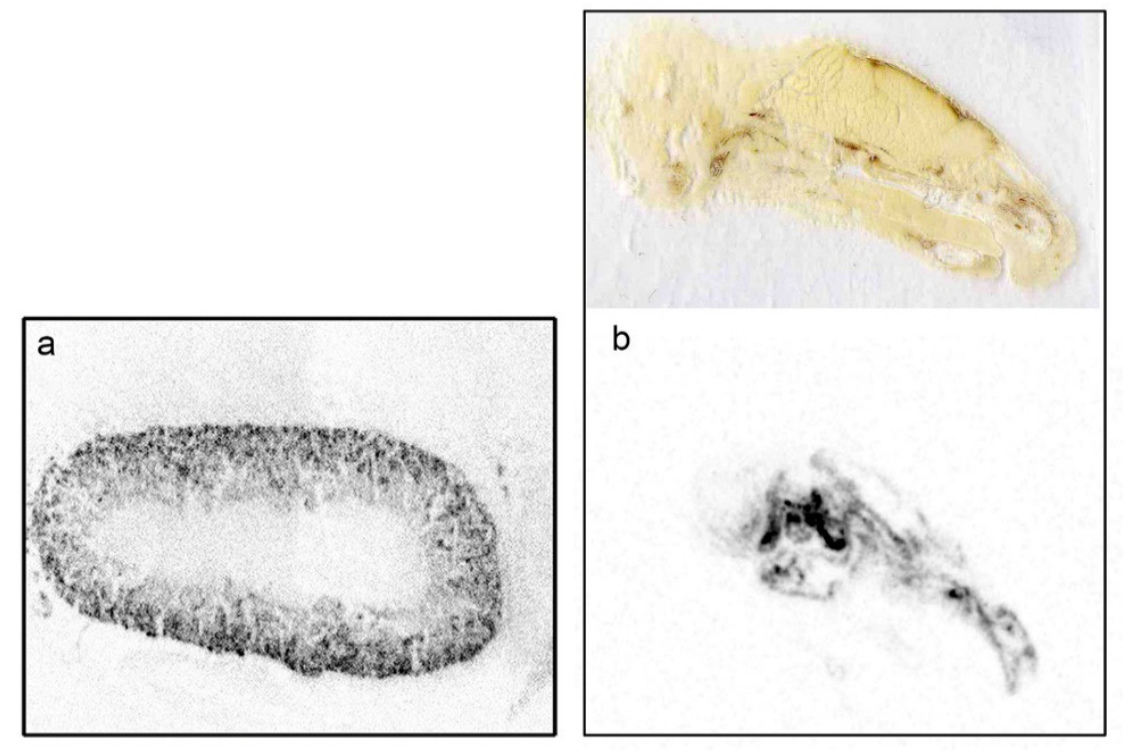

\section{Supplementary Figure S1:}

Mapping of [ $\left.{ }^{3} \mathbf{H}\right]-\mathbf{1}$ distribution in mouse renal (a) and naso-pharyngeal (b) tissues using the high-resolution $\mu$ radio imager and ß-radio imager. In vivo radiolabelling, $4 \mathrm{~h}$ after IV (a) and IN (b) injections of [ $\left.{ }^{3} \mathbf{H}\right]-\mathbf{1}$. Black area corresponds to the highest concentration of radioactivity. Highest level of radioactivity is seen in the cortical area of the kidney (a) and in the naso-pharyngeal tissues (b). 

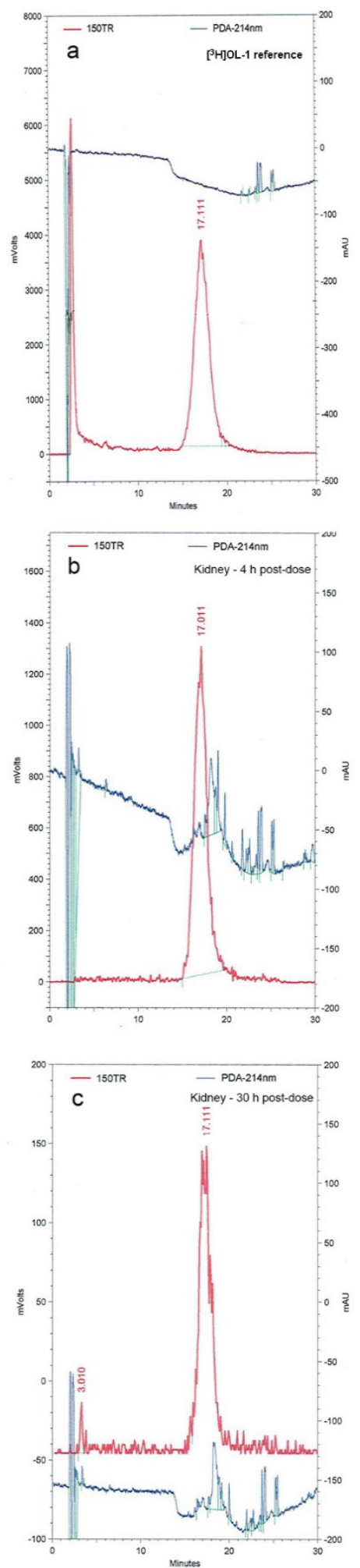

\section{Supplementary Figure S2:}

Representative HPLC profiles of 1-related molecular populations present in extracts of mouse renal tissue 4 and $30 \mathrm{~h}$ after intravenous bolus administration of $5 \mu \mathrm{Ci} / 100 \mu \mathrm{g}\left[{ }^{3} \mathbf{H}\right]-1$. Profiles in blue represent the $224 \mathrm{~nm}$ online spectrophotometer detection and in red the $150 \mathrm{TR}$ online radiometer detection. The radioactivity detection (mvolts) is shifted by 0.7 min compared to the spectrophotometer detection (mAU). Each Chromatographic profile is driven, integrated and analysed by the ChromQuest software. The peak area value of each peak of interest was calculated for percentage recovery calculation: 1 reference (a), renal extract at $4 \mathrm{~h}$ (b) and at $30 \mathrm{~h}$ (c) post-dose. 


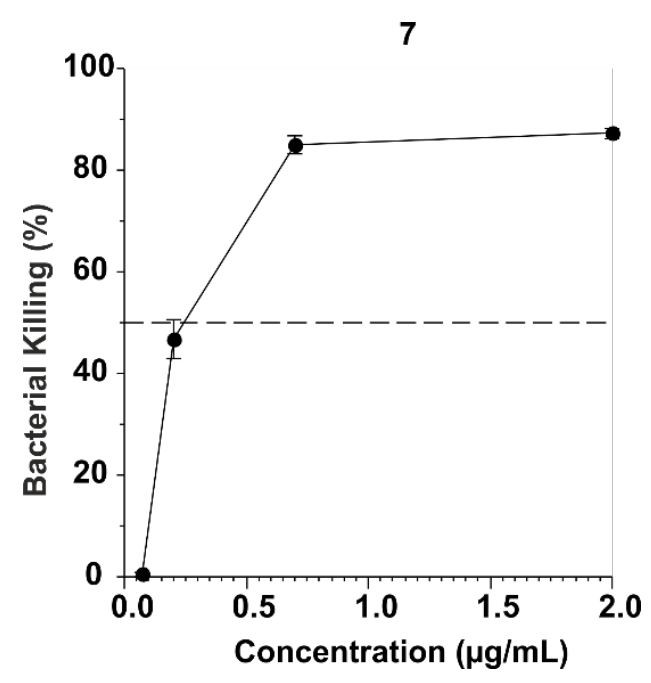

Supplementary Figure S3:

Bactericidal efficiency of dimer 7 against the germinated spores of $B$. anthracis. Increasing concentrations of 7 were incubated for $30 \mathrm{~min}$ with germinated spores of the $9602 \mathrm{P}$ strain. Dotted line represents $50 \%$ bacterial killing. Data are expressed as mean $\pm \mathrm{SEM}, \mathrm{n}=9$

\section{H-NMR : zone NH/N'H}

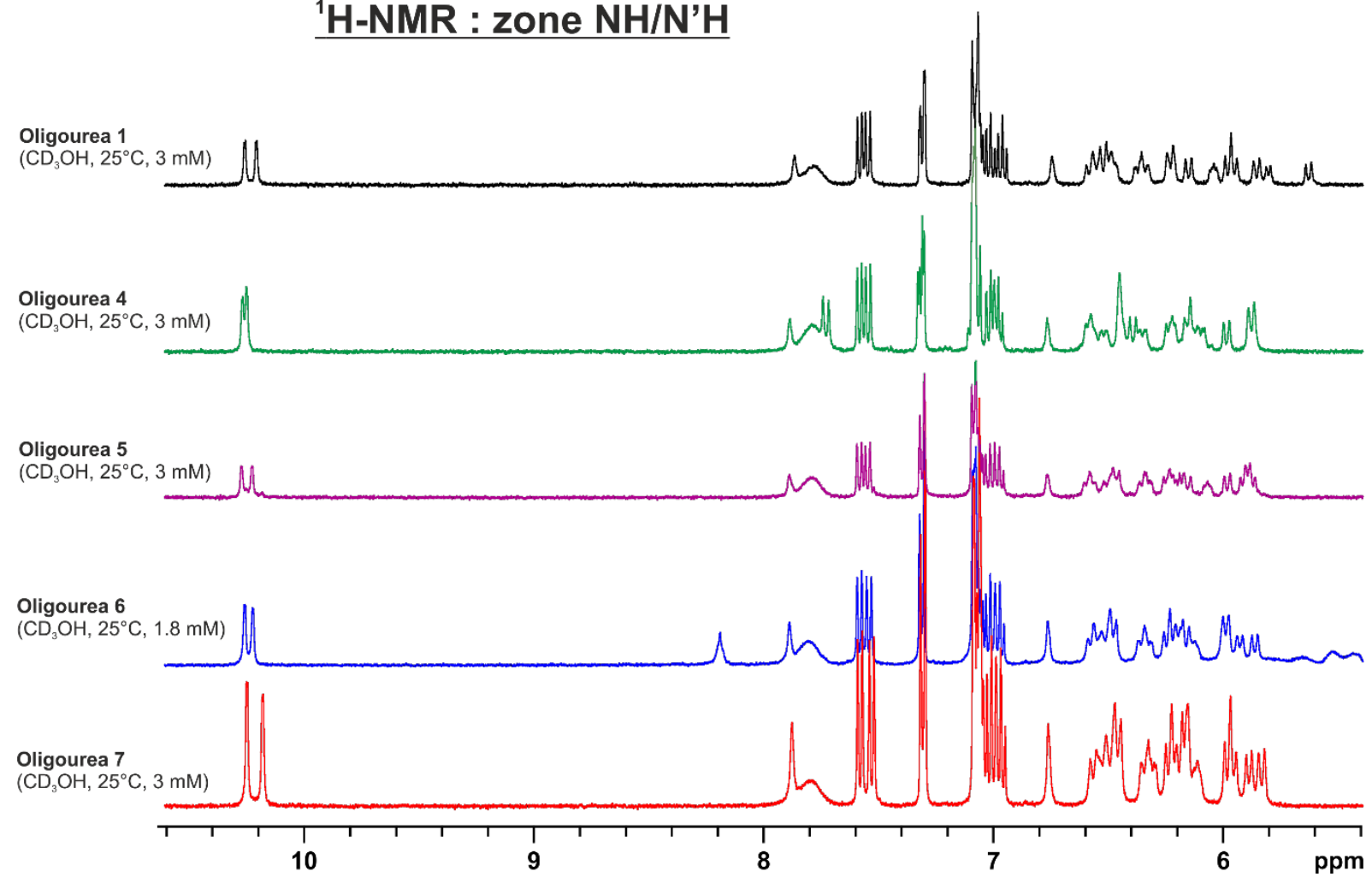

Supplementary Figure S4: Zoom of the NH/N'H region of the ${ }^{1} \mathrm{H}$ NMR spectra of 1 and 4-7 in $\mathrm{CD}_{3} \mathrm{OH}(400$ $\mathrm{MHz})$ at $25^{\circ} \mathrm{C}$. 


\section{${ }^{1} \mathrm{H}-\mathrm{NMR}$}

Oligourea 1

$\left(\mathrm{CD}_{3} \mathrm{OH}, 25^{\circ} \mathrm{C}, 3 \mathrm{mM}\right)$

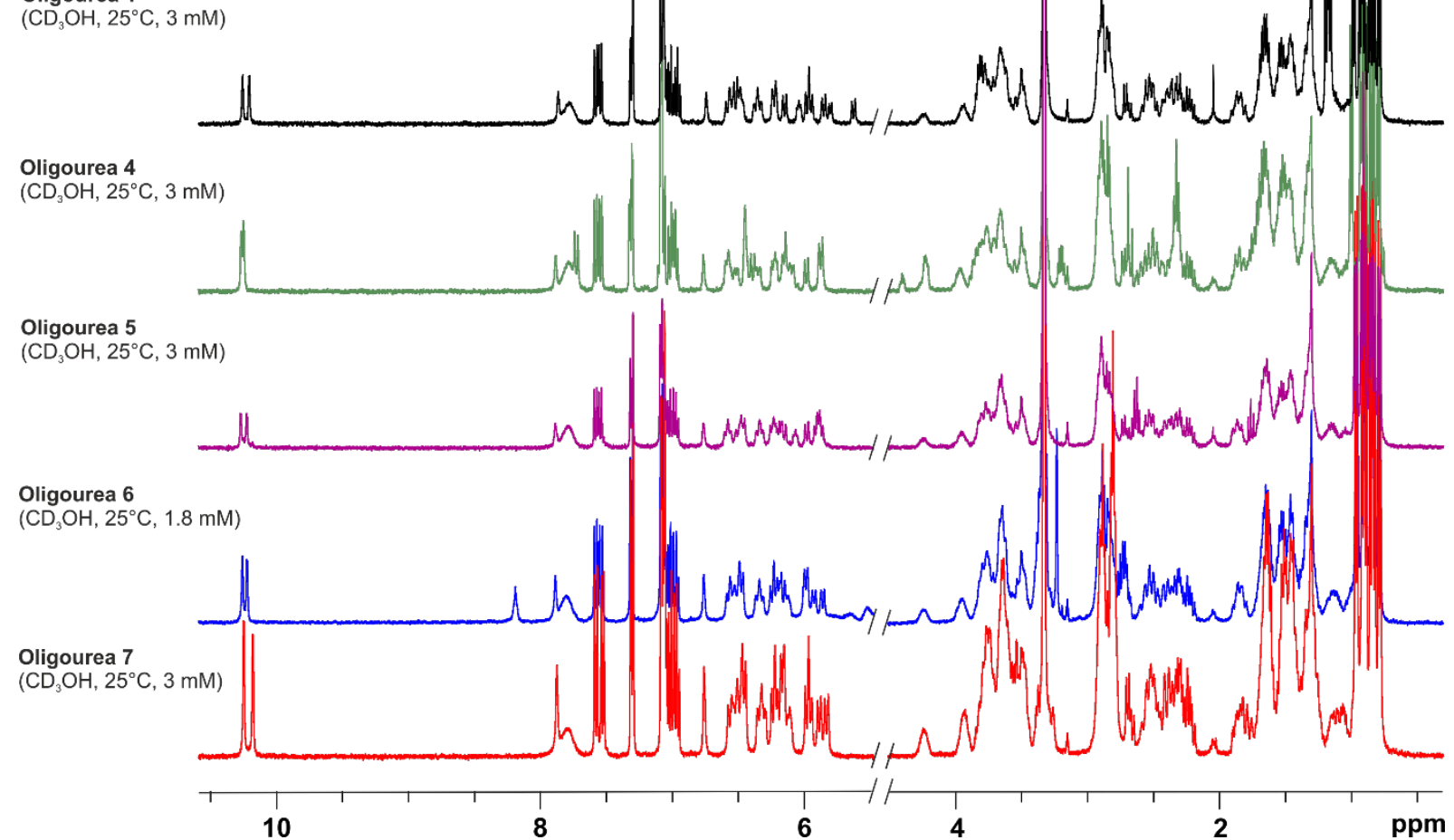

Supplementary Figure S5: ${ }^{1} \mathrm{H}$ NMR spectra of 1 and 4-7 in $\mathrm{CD}_{3} \mathrm{OH}(400 \mathrm{MHz})$ at $25^{\circ} \mathrm{C}$. 


\begin{tabular}{|c|c|c|c|c|c|c|c|c|c|c|c|c|}
\hline \multicolumn{2}{|c|}{ Residue } & \multirow{2}{*}{$\begin{array}{c}\text { NH } \\
6.22\end{array}$} & \multirow[t]{2}{*}{ N'H } & \multirow{2}{*}{$\begin{array}{r}{ }^{\boldsymbol{\alpha}} \mathbf{C H}^{\mathbf{1}} \\
2.30\end{array}$} & \multirow{2}{*}{$\begin{array}{c}{ }^{\alpha} \mathbf{C H}^{2} \\
2.26\end{array}$} & \multirow{2}{*}{$\begin{array}{r}{ }^{\beta} \mathbf{C H} \\
1.85 \\
1.37\end{array}$} & \multirow{2}{*}{$\frac{{ }^{\gamma} \mathbf{C H}}{3.51}$} & \multirow{2}{*}{$\frac{{ }^{8} \mathbf{C H}}{1.64}$} & \multirow{2}{*}{$\begin{array}{c}{ }^{8} \mathbf{C H} \\
0.87\end{array}$} & \multirow{2}{*}{$\begin{array}{c}\text { NH } \\
\text { side } \\
\text { chain } \\
\end{array}$} & \multirow[t]{2}{*}{ Arom } & \multirow[t]{2}{*}{$\Delta \delta\left({ }^{\alpha} \mathrm{CH}\right)$} \\
\hline $\mathbf{V a l}^{\gamma}$ & 1 & & & & & & & & & & & \\
\hline Lys $^{u}$ & 2 & 5.98 & 6.59 & 3.63 & 2.39 & 3.80 & $\begin{array}{l}1.65 \\
1.31\end{array}$ & 1.45 & 2.91 & 7.80 & & 1.24 \\
\hline $\operatorname{Trp}^{u}$ & 3 & 6.23 & 6.35 & 3.74 & 2.50 & 4.24 & $\begin{array}{l}2.84 \\
2.88\end{array}$ & & & 10.27 & $\begin{array}{l}7.01 / 7.08 \\
7.30 / 7.58\end{array}$ & 1.24 \\
\hline Lys $^{u}$ & 4 & 5.88 & 6.58 & 3.32 & 1.86 & 3.64 & $\begin{array}{l}1.04 \\
1.15\end{array}$ & 1.52 & 2.86 & 7.78 & & 1.46 \\
\hline Valu $^{u}$ & 5 & 6.15 & 6.52 & 3.66 & 2.34 & 3.48 & 1.51 & 0.81 & & & & 1.32 \\
\hline $\operatorname{Trp}^{u}$ & 6 & 6.39 & 6.44 & 3.78 & 2.54 & 3.96 & $\begin{array}{l}2.71 \\
2.86\end{array}$ & & & 10.25 & $\begin{array}{l}6.99 / 7.07 \\
7.32 / 7.55\end{array}$ & 1.24 \\
\hline Lys ${ }^{u}$ & 7 & 5.87 & 6.09 & 3.57 & 2.46 & 3.75 & $\begin{array}{l}1.65 \\
1.32\end{array}$ & 1.48 & 2.90 & 7.82 & & 1.11 \\
\hline Val $^{u}$ & 8 & 7.71 & 6.14 & 3.67 & 2.59 & 3.85 & 1.69 & 0.96 & & & & 1.08 \\
\hline \multicolumn{2}{|c|}{ Biotin } & \multicolumn{2}{|l|}{6.45} & \multicolumn{2}{|c|}{2.32} & 1.73 & 1.50 & 1.65 & 3.19 & & \multicolumn{2}{|c|}{$\begin{array}{r}\varepsilon^{\prime}=2.68 / 2.84 \\
\varepsilon^{\prime \prime}=4.22, \varepsilon^{\prime \prime \prime}=4.40\end{array}$} \\
\hline
\end{tabular}

Supplementary Table S2: ${ }^{1} \mathrm{H}$ NMR chemical shifts (in ppm) of 4 in $\mathrm{CD}_{3} \mathrm{OH}(400 \mathrm{MHz})$ at $25^{\circ} \mathrm{C}$.

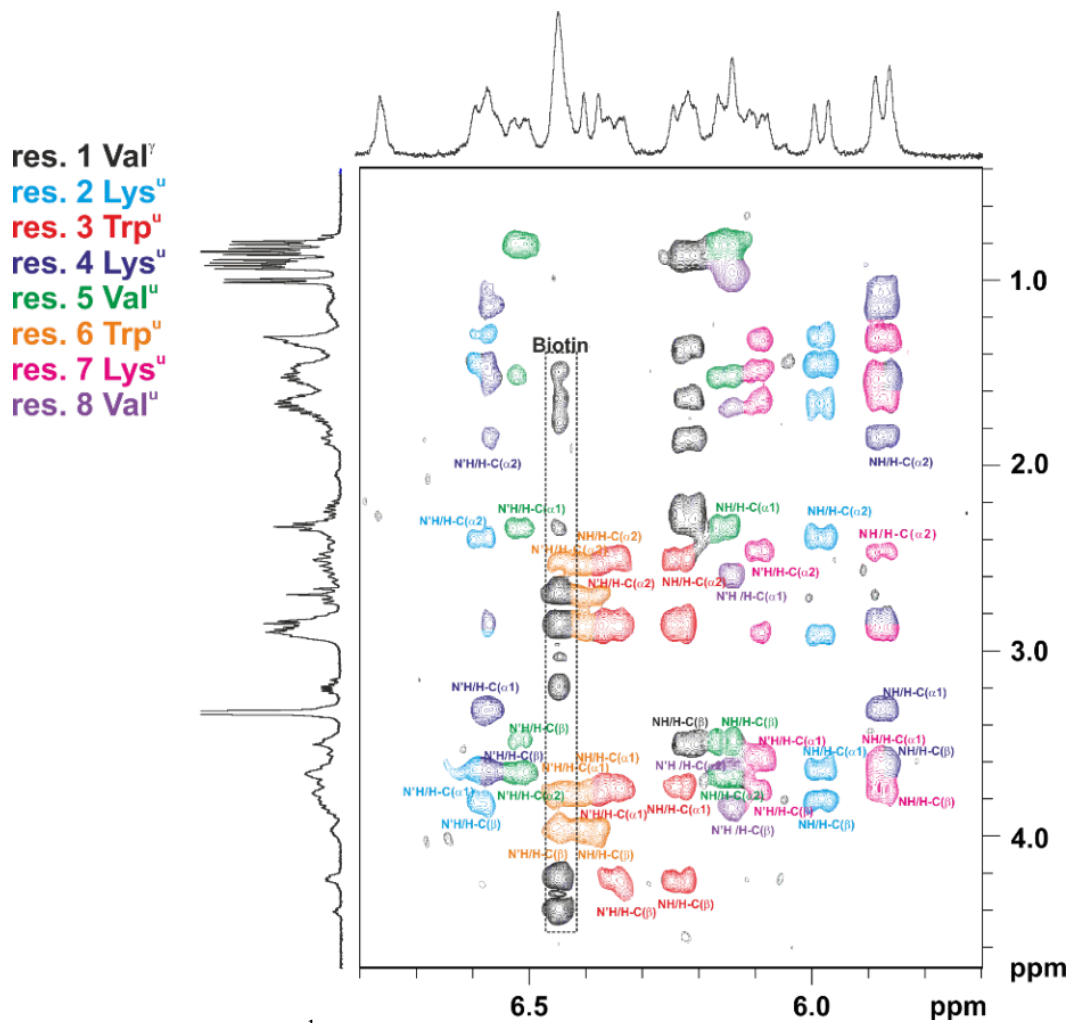

Supplementary Figure S6: Part of the ${ }^{1} \mathrm{H}$ NMR TOCSY spectrum of 4 in $\mathrm{CD}_{3} \mathrm{OH}(400 \mathrm{MHz})$ at $25^{\circ} \mathrm{C}$. 


\begin{tabular}{|c|c|c|c|c|c|c|c|c|c|c|c|c|}
\hline \multicolumn{2}{|c|}{ Residue } & \multirow{2}{*}{$\frac{\text { NH }}{6.22}$} & \multirow[t]{2}{*}{ N'H } & \multirow{2}{*}{$\frac{{ }^{\alpha} \mathbf{C H}^{\mathbf{1}}}{2.29}$} & \multirow{2}{*}{$\frac{{ }^{\alpha} \mathbf{C H}^{2}}{2.25}$} & \multirow{2}{*}{$\begin{array}{c}{ }^{\boldsymbol{\beta}} \mathbf{C H} \\
1.84 \\
1.37\end{array}$} & \multirow{2}{*}{$\frac{{ }^{\gamma} \mathbf{C H}}{3.51}$} & \multirow{2}{*}{$\frac{{ }^{\delta} \mathbf{C H}}{1.63}$} & \multirow{2}{*}{$\begin{array}{r}{ }^{\varepsilon} \mathbf{C H} \\
0.84\end{array}$} & \multirow{2}{*}{$\begin{array}{c}\text { NH } \\
\text { side } \\
\text { chain } \\
\end{array}$} & \multirow[t]{2}{*}{ Arom } & \multirow[t]{2}{*}{$\Delta \delta\left({ }^{\alpha} \mathrm{CH}\right)$} \\
\hline $\mathbf{V a l}^{\gamma}$ & 1 & & & & & & & & & & & \\
\hline Lys ${ }^{\mathbf{u}}$ & 2 & 5.98 & 6.58 & 3.63 & 2.39 & 3.81 & $\begin{array}{l}1.67 \\
1.27\end{array}$ & 1.42 & 2.91 & 7.80 & & 1.24 \\
\hline $\operatorname{Trp}^{u}$ & 3 & 6.23 & 6.34 & 3.72 & 2.49 & 4.23 & $\begin{array}{l}2.83 \\
2.87\end{array}$ & & & 10.26 & $\begin{array}{l}6.95 / 7.08 \\
7.32 / 7.58\end{array}$ & 1.23 \\
\hline Lys ${ }^{u}$ & 4 & 5.86 & 6.56 & 3.31 & 1.84 & 3.65 & $\begin{array}{l}1.18 \\
1.06\end{array}$ & 1.52 & 2.85 & 7.77 & & 1.47 \\
\hline Val $^{\mathbf{u}}$ & 5 & 6.12 & 6.49 & 3.65 & 2.32 & 3.47 & 1.51 & 0.80 & & & & 1.33 \\
\hline $\operatorname{Trp}^{u}$ & 6 & 6.44 & 6.47 & 3.79 & 2.53 & 3.95 & $\begin{array}{l}2.86 \\
2.69\end{array}$ & & & 10.21 & $\begin{array}{l}6.93 / 7.06 \\
7.29 / 7.53\end{array}$ & 1.26 \\
\hline Lys ${ }^{u}$ & 7 & 5.90 & 6.31 & 3.55 & 2.42 & 3.74 & $\begin{array}{l}1.64 \\
1.30\end{array}$ & 1.47 & 2.88 & 7.75 & & 1.13 \\
\hline Val $^{\mathbf{u}}$ & 8 & 5.88 & 6.06 & 3.63 & 2.55 & 3.67 & 1.64 & 0.93 & & & & 1.08 \\
\hline \multicolumn{2}{|c|}{$\mathrm{HS}\left(\mathrm{CH}_{2}\right)_{2} \mathrm{NH}-$} & 6.17 & & \multicolumn{2}{|c|}{3.31} & $\begin{array}{l}2.62 \\
1.75\end{array}$ & & & & & & \\
\hline
\end{tabular}

Supplementary Table S3: ${ }^{1} \mathrm{H}$ NMR chemical shifts (in ppm) of 5 in $\mathrm{CD}_{3} \mathrm{OH}(400 \mathrm{MHz})$ at $25^{\circ} \mathrm{C}$.

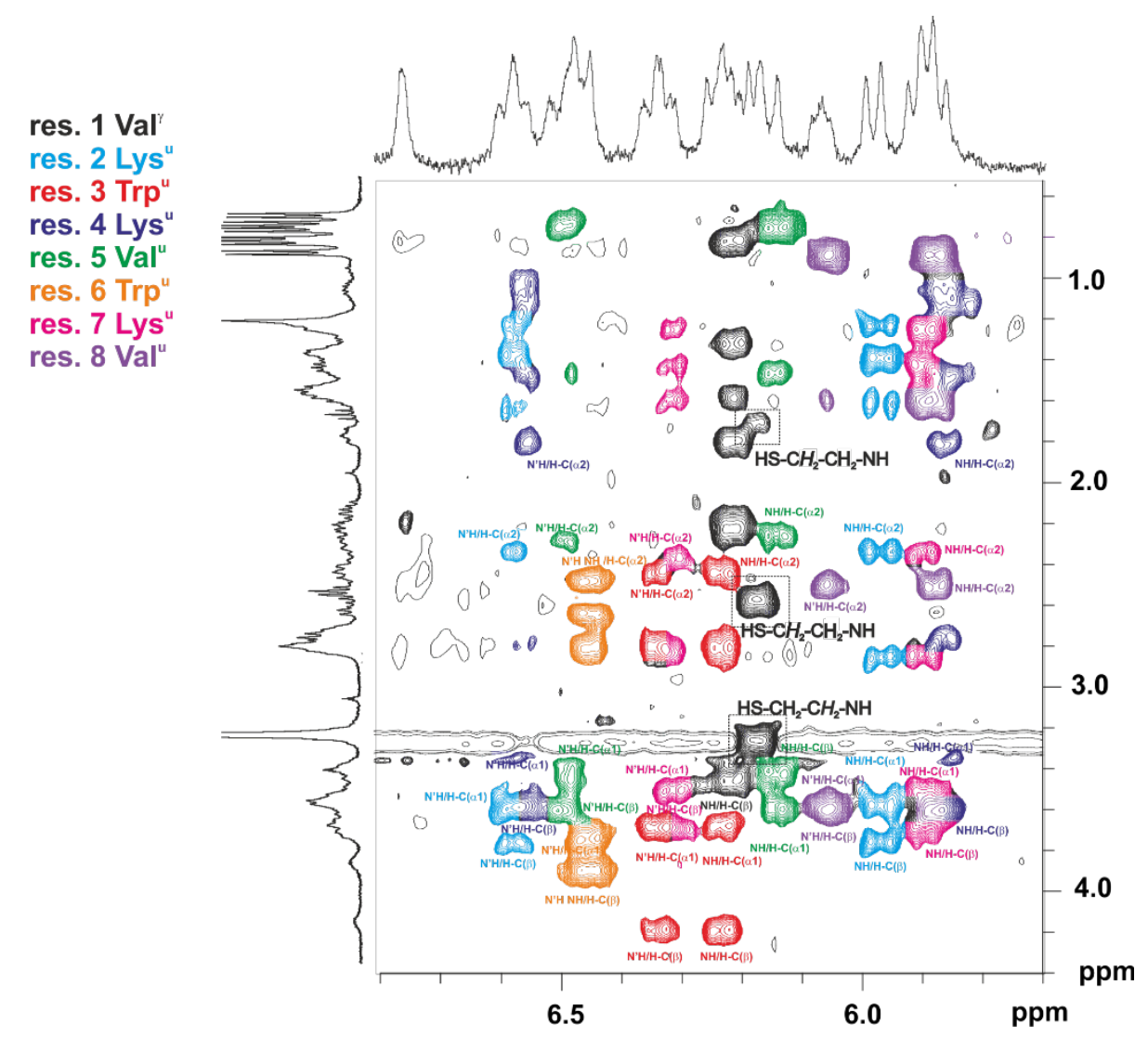

Supplementary Figure S7: Part of the ${ }^{1} \mathrm{H}$ NMR TOCSY spectrum of 5 in $\mathrm{CD}_{3} \mathrm{OH}(400 \mathrm{MHz})$ at $25^{\circ} \mathrm{C}$. 


\begin{tabular}{|c|c|c|c|c|c|c|c|c|c|c|c|c|}
\hline Residue & & NH & $\mathbf{N}^{\prime} \mathbf{H}$ & ${ }^{\alpha} \mathrm{CH}^{1}$ & ${ }^{\alpha} \mathrm{CH}^{2}$ & ${ }^{\beta} \mathrm{CH}$ & ${ }^{\gamma} \mathbf{C H}$ & ${ }^{\delta} \mathrm{CH}$ & ${ }^{8} \mathrm{CH}$ & $\begin{array}{c}\text { NH } \\
\text { side } \\
\text { chain }\end{array}$ & Arom & $\Delta \delta\left({ }^{\alpha} \mathrm{CH}\right)$ \\
\hline $\mathbf{V a l}^{\gamma}$ & $1 / 1 '$ & 6.22 & & 2.29 & 2.25 & $\begin{array}{l}1.85 \\
1.37\end{array}$ & 3.50 & 1.64 & 0.87 & & & \\
\hline Lys ${ }^{u}$ & $2 / 2$ & 5.97 & 6.57 & 3.65 & 2.39 & 3.79 & $\begin{array}{l}1.66 \\
1.29\end{array}$ & 1.45 & 2.89 & 7.78 & & 1.26 \\
\hline $\operatorname{Trp}^{\mathrm{u}}$ & $3 / 3$ & 6.29 & 6.35 & 3.73 & 2.50 & 4.25 & $\begin{array}{l}2.88 \\
2.83\end{array}$ & & & 10.25 & $\begin{array}{l}7.58 / 7.30 \\
7.08 / 6.96\end{array}$ & 1.23 \\
\hline Lys ${ }^{u}$ & $4 / 4$ & 5.86 & 6.54 & 3.32 & 1.83 & 3.65 & $\begin{array}{l}1.11 \\
0.97\end{array}$ & 1.54 & 2.82 & 7.79 & & 1.49 \\
\hline Val $^{u}$ & $5 / 5$ & 6.16 & 6.51 & 3.66 & 2.33 & 3.48 & 1.52 & 0.80 & & & & 1.33 \\
\hline $\operatorname{Trp}^{u}$ & $6 / 6^{\prime}$ & 6.46 & 6.48 & 3.79 & 2.54 & 3.94 & $\begin{array}{l}2.69 \\
2.54\end{array}$ & & & 10.22 & $\begin{array}{l}7.53 / 7.32 \\
7.08 / 6.95\end{array}$ & 1.25 \\
\hline Lys ${ }^{u}$ & $7 / 7$ & 6.00 & 6.32 & 3.54 & 2.43 & 3.74 & $\begin{array}{l}1.63 \\
1.31\end{array}$ & 1.48 & 2.87 & 7.83 & & 1.11 \\
\hline Val $^{u}$ & 8/8 & 5.92 & 6.12 & 3.63 & 2.57 & 3.66 & 1.65 & 0.93 & & & & 1.06 \\
\hline $\mathrm{CH}_{2} \mathrm{~S}\left(\mathrm{CH}_{2}\right)_{2} \underline{\mathrm{NH}} \cdot$ & & 6.18 & & 3.37 & & 2.73 & $N D$ & & & & & \\
\hline$\left(\mathrm{CH}_{2}\right)_{2} \underline{\mathrm{NH}}$ & & 8.19 & & 3.31 & & & & & & & & \\
\hline
\end{tabular}

Supplementary Table S4: ${ }^{1} \mathrm{H}$ NMR chemical shifts (in ppm) of 6 in $\mathrm{CD}_{3} \mathrm{OH}(400 \mathrm{MHz})$ at $25^{\circ} \mathrm{C}(\mathrm{ND}=$ none determined).

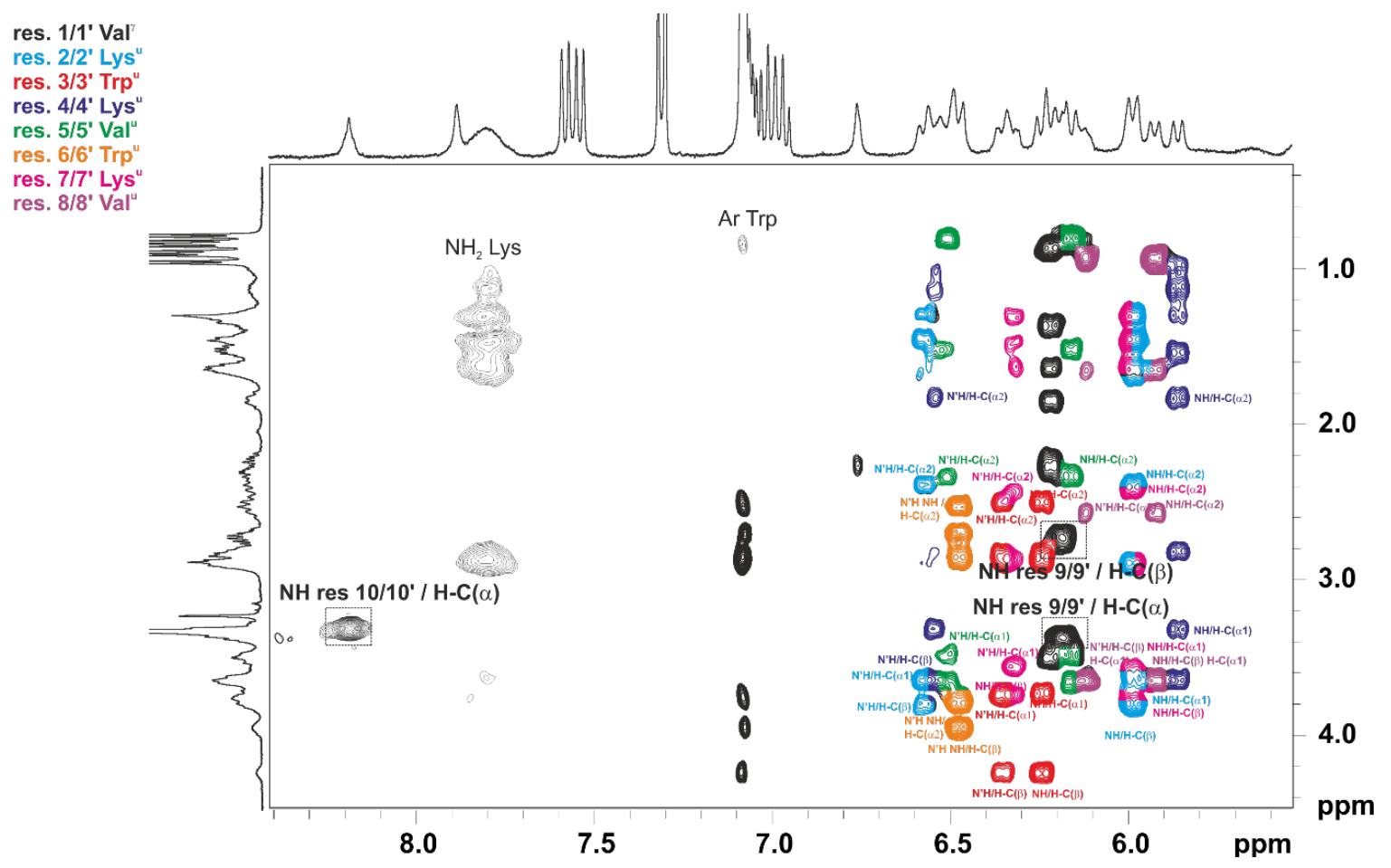

Supplementary Figure S8: Part of the ${ }^{1} \mathrm{H}$ NMR TOCSY spectrum of 6 in $\mathrm{CD}_{3} \mathrm{OH}(400 \mathrm{MHz})$ at $25^{\circ} \mathrm{C}$. 


\begin{tabular}{|c|c|c|c|c|c|c|c|c|c|c|c|c|}
\hline \multicolumn{2}{|c|}{ Residue } & \multirow{2}{*}{$\frac{\mathbf{N H}}{6.21}$} & \multirow[t]{2}{*}{ N'H } & \multirow{2}{*}{$\begin{array}{r}{ }^{\boldsymbol{\alpha}} \mathbf{C H}^{\mathbf{1}} \\
2.28\end{array}$} & \multirow{2}{*}{$\frac{{ }^{\alpha} \mathbf{C H}^{2}}{2.23}$} & \multirow{2}{*}{$\begin{array}{l}{ }^{\beta} \mathbf{C H} \\
1.85 \\
1.37\end{array}$} & \multirow{2}{*}{$\frac{{ }^{\gamma} \mathbf{C H}}{3.49}$} & \multirow{2}{*}{$\frac{{ }^{\delta} \mathbf{C H}}{1.64}$} & \multirow{2}{*}{$\begin{array}{l}{ }^{{ }^{8} \mathbf{C H}} \\
0.86\end{array}$} & \multirow{2}{*}{$\begin{array}{c}\text { NH } \\
\text { side } \\
\text { chain } \\
\end{array}$} & \multirow[t]{2}{*}{ Arom } & \multirow[t]{2}{*}{$\Delta \delta\left({ }^{\alpha} \mathrm{CH}\right)$} \\
\hline $\mathbf{V a l}^{\gamma}$ & $1 / 1^{\prime}$ & & & & & & & & & & & \\
\hline Lys $^{u}$ & $2 / 2$ & 5.95 & 6.56 & 3.64 & 2.39 & 3.79 & $\begin{array}{l}1.66 \\
1.29\end{array}$ & 1.45 & 2.90 & 7.80 & & 1.25 \\
\hline $\operatorname{Trp}^{u}$ & $3 / 3$ & 6.23 & 6.34 & 3.73 & 2.50 & 4.24 & $\begin{array}{l}2.87 \\
2.83\end{array}$ & & & 10.24 & $\begin{array}{l}6.85 / 7.08 \\
7.30 / 7.57\end{array}$ & 1.23 \\
\hline Lys ${ }^{u}$ & $4 / 4$ & 5.83 & 6.52 & 3.28 & 1.78 & 3.63 & $\begin{array}{l}1.10 \\
0.95\end{array}$ & 1.51 & 2.79 & 7.76 & & 1.48 \\
\hline Val $^{u}$ & $5 / 5$ & 6.16 & 6.49 & 3.64 & 2.32 & 3.48 & 1.52 & 0.80 & & & & 1.32 \\
\hline $\operatorname{Trp}^{u}$ & $6 / 6$ & 6.44 & 6.47 & 3.76 & 2.52 & 3.93 & $\begin{array}{l}2.66 \\
2.52\end{array}$ & & & 10.17 & $\begin{array}{l}6.92 / 7.05 \\
7.28 / 7.53\end{array}$ & 1.24 \\
\hline Lys $^{u}$ & $7 / 7$ & 5.95 & 6.30 & 3.57 & 2.41 & 3.75 & $\begin{array}{l}1.64 \\
1.29\end{array}$ & 1.45 & 2.88 & 7.80 & & 1.16 \\
\hline $\mathrm{Val}^{\mathrm{u}}$ & $8 / 8$ & 5.88 & 6.11 & 3.62 & 2.55 & 3.65 & 1.65 & 0.93 & & & & 1.07 \\
\hline \multicolumn{2}{|c|}{$-\mathrm{S}\left(\mathrm{CH}_{2}\right)_{2} \underline{\underline{\mathrm{NH}}-}$} & 6.16 & & \multicolumn{2}{|c|}{3.38} & 2.81 & & & & & & \\
\hline
\end{tabular}

Supplementary Table S5: ${ }^{1} \mathrm{H}$ NMR chemical shifts (in ppm) of 7 in $\mathrm{CD}_{3} \mathrm{OH}(400 \mathrm{MHz})$ at $25^{\circ} \mathrm{C}$.

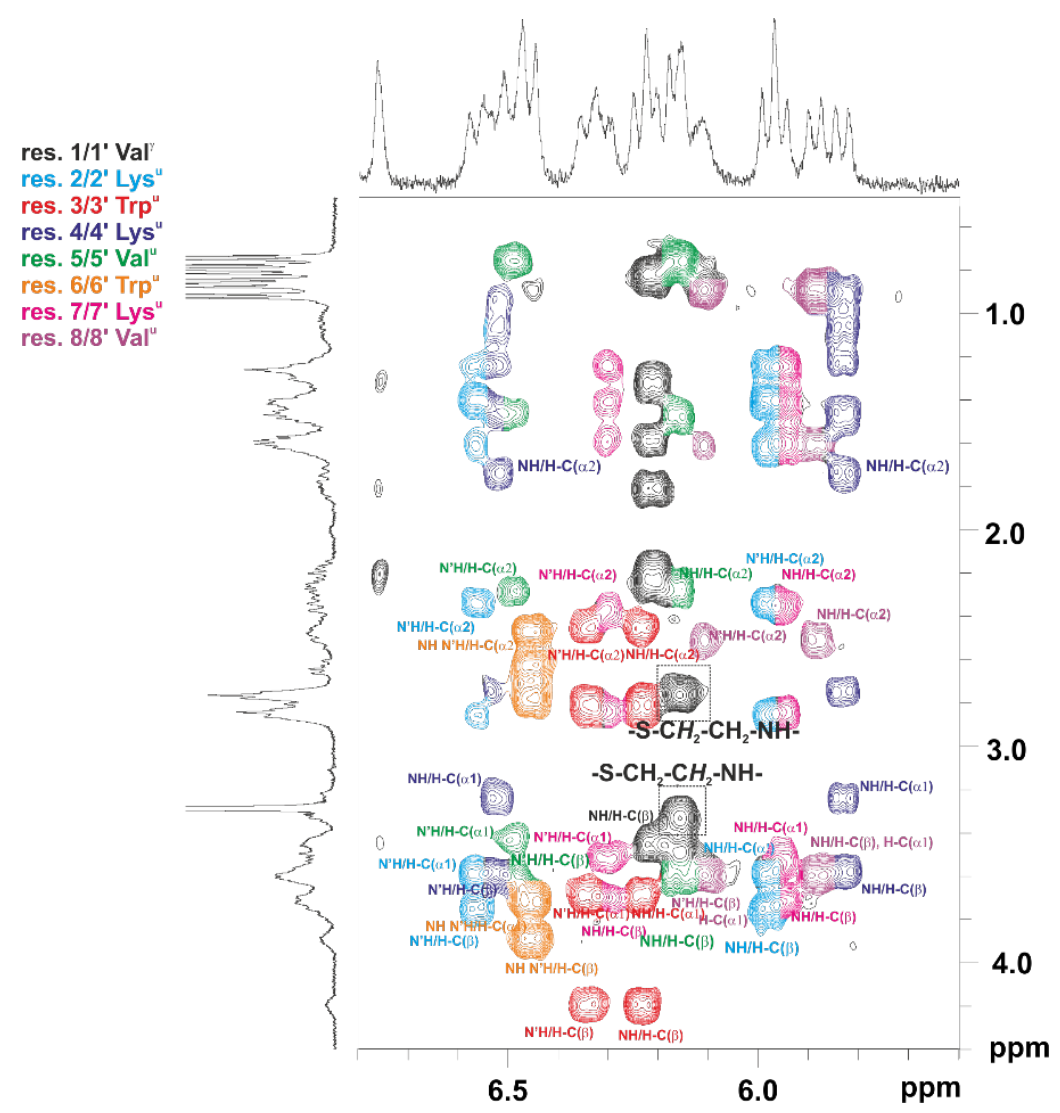

Supplementary Figure S9: Part of the ${ }^{1} \mathrm{H}$ NMR TOCSY spectrum of 7 in $\mathrm{CD}_{3} \mathrm{OH}(400 \mathrm{MHz})$ at $25^{\circ} \mathrm{C}$. 


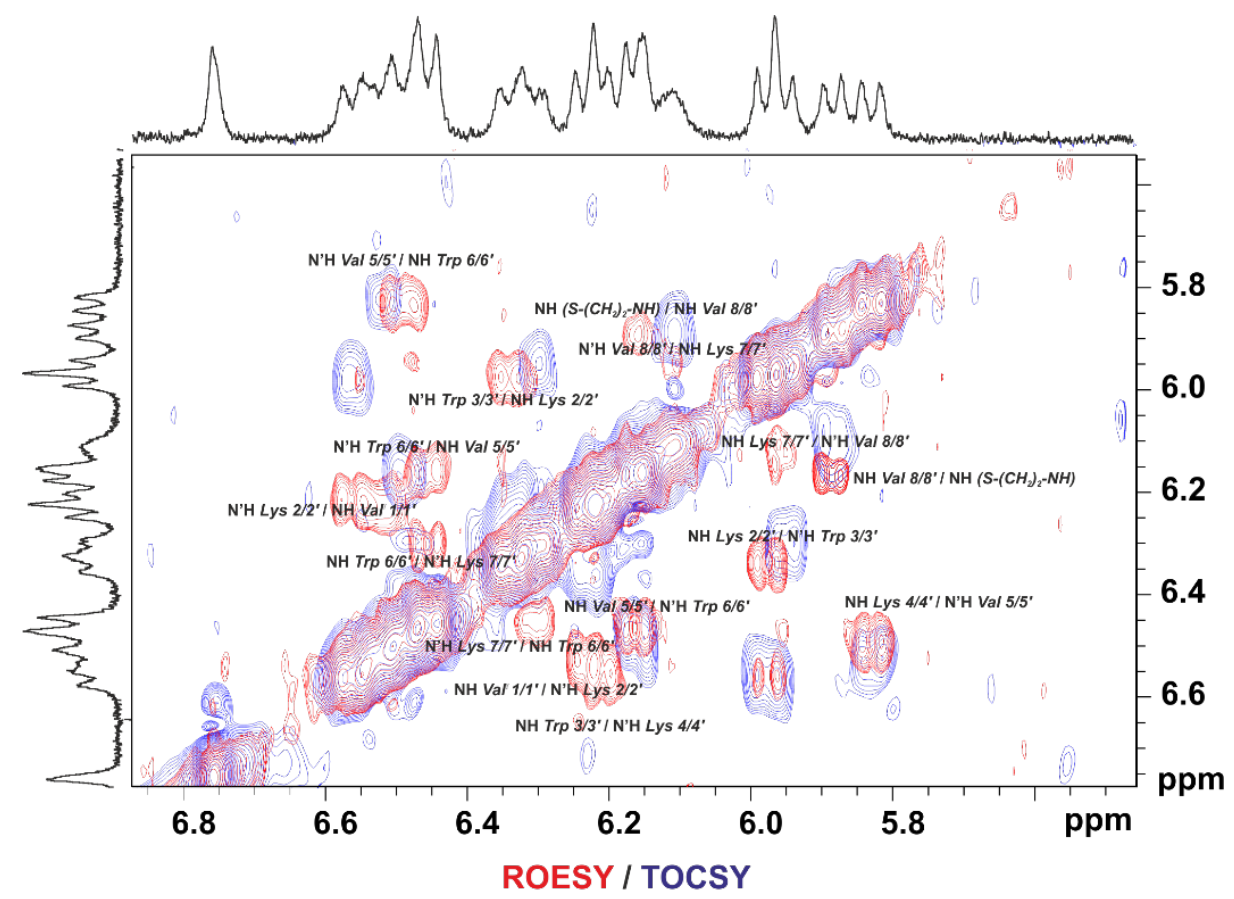

Supplementary Figure S10: Superimposition of the NH/N'H fingerprint region of the ${ }^{1} \mathrm{H}$ NMR TOCSY and the ROESY spectra (mixing time of $300 \mathrm{~ms}$ ) of 7 in $\mathrm{CD}_{3} \mathrm{OH}(400 \mathrm{MHz})$ at $25^{\circ} \mathrm{C}$. 